Volume 113

Issue 3 Dickinson Law Review - Volume 113,

2008-2009

$1-1-2009$

\title{
John Leland and James Madison: Religious Influence on the Ratification of the Constitution and on the Proposal of the Bill of Rights
}

Mark S. Scarberry

Follow this and additional works at: https://ideas.dickinsonlaw.psu.edu/dlra

\section{Recommended Citation}

Mark S. Scarberry, John Leland and James Madison: Religious Influence on the Ratification of the Constitution and on the Proposal of the Bill of Rights, 113 DICK. L. REV. 733 (2009).

Available at: https://ideas.dickinsonlaw.psu.edu/dlra/vol113/iss3/3

This Article is brought to you for free and open access by the Law Reviews at Dickinson Law IDEAS. It has been accepted for inclusion in Dickinson Law Review by an authorized editor of Dickinson Law IDEAS. For more information, please contactlja10@psu.edu. 


\section{John Leland and James Madison: Religious Influence on the Ratification of the Constitution and on the Proposal of the Bill of Rights}

\section{Mark S. Scarberry*}

Leland's self-written Epitaph: "Here lies the body of John Leland, who labored 67 years to promote piety and vindicate the civil and religious rights of all men."

"He played a substantial part in molding [an] American tradition that is full of meaning to all of us today-the separation of church and state in the United States... . Much of Leland's sixty-seven year career as a Baptist evangelist was expended in fighting to remove [religious] disabilities-not only for Baptists but for persons of all faiths, Christian and non-Christian, and even for those who held no recognized religious faith. ... [H]e was as courageous and resourceful a champion of the rights of conscience as America has produced."2

* Copyright (C) 2008 Mark S. Scarberry, Professor of Law, Pepperdine University School of Law. I would like to thank Professor Edward J. Larson for his helpful comments and encouragement.

1. L.F. Green, Further Sketches of the Life of John Leland, in JOHN LELAND, THE WRITINGS OF THE LATE ELDER JOHN LELAND 41, 50 (L.F. Greene ed., 1845), available on Google Books at http://books.google.com/books? id=bMAiAAAAMAAJ. The epitaph was written by Leland, except of course for the number sixty-seven, which could not be calculated until his death. See JOHN LELAND, Events in the Life of John Leland: Written by Himself, in JOHN LELAND, supra, at 9, 38 [hereinafter Events].

2. L.H. Butterfield, Elder John Leland, Jeffersonian Itinerant, 62 PROC. OF THE AM. ANTIQUARIAN SOC'Y 155, 156-57 (1952) (quotation reproduced more fully infra text accompanying note 35 ), reprinted in COLONIAL BAPTISTS AND SOUTHERN REVIVALS: AN ORIGINAL ANTHOLOGY (1980). Lyman Henry Butterfield served as an associate editor of the first five volumes of The Papers of Thomas Jefferson (published by Princeton University Press) and then as Director of the Institute of Early American History and Culture at Williamsburg; from 1954 to 1975 he served as "editor-in-chief of the Adams Papers, and under his active editorship or editorial direction appeared the first twenty volumes of [t]his monumental project, conducted with the cooperation of the Adams family, the sponsorship of the Massachusetts Historical Society, and the imprint of the Belknap Press of Harvard University Press." William Bentinck Smith, In Memoriam: 


\section{INTRODUCTION}

The symposium topic ${ }^{3}$ is the effect of religion on elections, and the legislation that is enacted as a result of that effect. ${ }^{4}$ The topic can be seen from two somewhat distinct perspectives. To the extent that religion affects elections, it may result in the election of different persons from those who otherwise would have been elected, and those different persons may then enact different legislation (including constitutional provisions) from that which otherwise would have been enacted. On the other hand, to the extent that religious influence on elections is feared, the potential religious influence or effect may cause those who fear it to enact legislation (again, including constitutional provisions) intended to prevent religious influence on elections.

Consider the first perspective. This article suggests that concerns of Virginia Baptists about religious liberty-including particularly the concerns of one Baptist preacher, John Leland-played a substantial role in James Madison's elections to the Virginia ratifying convention in March of 1788 and to the First Congress in February of $1789 .^{5}$ Those elections, in turn, were key events in the ratification of the Constitution and in the adoption of the Bill of Rights.

Consider the second perspective. Under one interpretation, the Establishment Clause of the First Amendment responds to some degree to the fear that religion could have too great an effect on our government, through elections or otherwise. Thus, it is argued, the Establishment Clause creates a "wall of separation" between government and religion, in part to prevent religion from influencing government too greatly. ${ }^{6}$

Lyman Butterfield (1909-1982): Editor on the Grand Scale, 55 NEW ENG. Q. 440, 440-42 (1982), available at http://www.jstor.org/stable/365087. Bentinck-Smith notes that Butterfield "was not one who found much use for religious symbols or for religion as an institution." Id. at 446.

3. This article is an expansion of a presentation made at the March 18, 2008 Boston College Law and Religion Program Symposium, Electing Faith: The Intersection of Law and Religion in Politics Around the World.

4. The author thanks the Boston College Law School's Law and Religion Program for inviting him to speak at the symposium. The symposium organizers were prescient; they could not have realized at the time the symposium was organized that religion would play such an important role in the presidential election of 2008.

5. As will be explained below, this suggestion is not new, though more can usefully be said about it than has been said to this point.

6. See, e.g., Philip Hamburger, Separation of Church and State 13-14 (Harvard Univ. Press 2002) (noting critically the development of this view); LAURENCE H. TRIBE, AMERICAN CONSTITUTIONAL LAW 1158-59, 1275-84 (2d ed., 1988) (noting that one school of thought that influenced drafters of First Amendment was to wall the church off from the state in order to protect secular interests "against ecclesiastical depredations and incursions" (quoting MARK DEWOLFE Howe, ThE GARDEN AND THE WILDERNESS 2 (1965)) but arguing that "when the wall between church and state prevents religion from entering politics, it proves too formidable a barrier"); Steven G. Gey, Unity of the 
Even where the Establishment Clause might not create a legal obligation, it is suggested that the policies behind the Establishment Clause, and other concerns about the preservation of our liberal democracy, require religious groups and religiously-motivated persons as a matter of good citizenship to refrain from influencing the government, or at least to recast their arguments so that they do not rely on religious grounds. ${ }^{7}$ The "wall of separation," it is further argued, limits the permissible activities of tax-exempt religious groups in elections, ${ }^{8}$ or at least provides a policy basis for legislation discouraging such activities. ${ }^{9}$

Philip Hamburger's insightful book Separation of Church and State $^{10}$ casts grave doubt on this interpretation of the Establishment Clause. ${ }^{11}$ This article casts further doubt on it and in particular considers

Graveyard and the Attack on Constitutional Secularism, 2004 BYU L. REV. 1005, 102129 (2004); William P. Marshall, The Other Side of Religion, 44 HASTINGs L.J. 843, 85963 (1993). For a recent discussion of the role of the Establishment Clause in protecting religion from being corrupted by government, including a discussion of Leland's views on the subject, see Andrew Koppelman, Corruption of Religion and the Establishment Clause, 50 WM. \& MARY L. REV. (forthcoming 2009), available at http://ssrn.com/ abstract $=1268406(2008)$.

7. See, e.g., Robert Audi, Religious Commitment and Secular Reason (2000); JOHN RAWLS, The Idea of Public Reason Revisited, in THE LAW OF PEOPLES 131 (1999). For trenchant criticism of this view, see Steven D. Smith, Recovering (from) Enlightenment, 41 SAN DiEgo L. REv. 1263 (2004), and Michael W. McConnell, Five Reasons to Reject the Claim that Religious Arguments Should Be Excluded from Democratic Deliberation, 1999 UTAH L. REV. 639.

8. See, e.g., Oliver A. Houck, On the Limits of Charity: Lobbying, Litigation, and Electoral Politics by Charitable Organizations under the Internal Revenue Code and Related Laws, 69 BROOK. L. REV. 1, 52-62 (2003).

9. See, e.g., Donald B. Tobin, Political Campaigning by Churches and Charities: Hazardous for 501(c)(3)s, Dangerous for Democracy, 95 GEO. L.J. 1313, 1320-35 (2007). For different views, see Johnny Rex Buckles, Is the Ban on Participation in Political Campaigns by Charities Essential to Their Vitality and Democracy? A Reply to Professor Tobin, 42 U. RICH. L. REv. 1057 (2008); Steffen N. Johnson, Of Politics and Pulpits: A First Amendment Analysis of IRS Restrictions on the Political Activities of Religious Organizations, 42 B.C. L. REV. 875 (2001); Lloyd Hitoshi Mayer, Grasping Smoke: Enforcing the Ban on Political Activity by Charities, 6 FIRST AMEND. L. REv. 1 (2007); Jennifer M. Smith, Morse Code, Da Vinci Code, Tax Code and . . Churches: An Historical and Constitutional Analysis of Why Section 501(c)(3) Does Not Apply to Churches, 23 J.L. \& PoL. 41 (2007); Mark Totten, The Politics of Faith: Rethinking the Prohibition on Political Campaign Intervention, 18 STAN. L. \& POL'Y REV. 298 (2007).

10. HAMBURGER, supra note 6.

11. See id. at 10-14 \& passim. For further criticisms of this interpretation, see, for example, Patrick M. Garry, The Democratic Aspect of the Establishment Clause: A Refutation of the Argument that the Clause Serves to Protect Religious or Nonreligious Minorities, 59 MERCER L. REV. 595 (2008); Frederick Mark Gedicks, Spirituality, Fundamentalism, Liberty: Religion at the End of Modernity, 54 DEPAUL L. REV. 1197 (2005); Scott C. Idleman, Religious Premises, Legislative Judgments, and the Establishment Clause, 12 CORNELl J.L. \& PUB. POL'Y 1 (2002); Michael W. McConnell, Establishment and Disestablishment at the Founding, Part I: Establishment of Religion, 44 WM. \& MARY L. REV. 2105 (2003); McConnell, supra note 7; Richard John Neuhaus, A New Order of Religious Freedom, 60 GEo. WASH. L. REV. 620 (1992); Michael J. 
whether Leland's role in Madison's elections may provide context for interpretation of the Establishment Clause. Professor Hamburger discusses Leland's role to some extent, as do others, ${ }^{12}$ but there is more

Perry, Why Political Reliance on Religiously Grounded Morality Does Not Violate the Establishment Clause, 42 WM. \& MARY L. ReV. 663 (2001); Steven D. Smith, How is America "Divided by God"?, 27 Miss. C. L. REV. 141 (2007-08). For equivocal (or nuanced) views with regard to whether religious arguments should be recast in secular terms, see Kent Greenawalt, Private Consciences and Public Reasons (1995); Michael J. Perry, Religion in Politics: Constitutional and Moral Perspectives (1997).

12. The two most important sources of information about John Leland are (1) his collected writings, JOHN LELAND, THE WRITINGS OF THE LATE ELDER JOHN LELAND (L.F. Greene ed., 1845) [hereinafter WRITINGS] (including various works separately cited in this article, as noted, for example, supra note 1) (out-of-print photo. reprint, New York: Arno Press 1969) (out-of-print reprint (probably photographic) under title THE WRITINGS OF JOHN LELAND, Gallatin, TN: Church History Research and Archives 1986), available at http://books.google.com/books?id=bMAiAAAAMAAJ; and (2) Lyman Butterfield's 1952 article, Butterfield, supra note 2. See also WILlIAM R. ESTEP, REVOLUTION WITHIN THE Revolution 149-75, 199 (1990); Nathan O. Hatch, THE Democratization of AMERICAN CHRISTIANITY 95-101 (1989); Nathan O. Hatch, The Democratization of Christianity and the Character of American Politics, in RELIGION AND AMERICAN Politics: From the Colonial Period to the Present 93, 109-13 (Mark A. Noll \& Luke E. Harlow eds., 2d ed. 2007); Carl H. Esbeck, Dissent and Disestablishment: The Church-State Settlement in the Early American Republic, 2004 BYU L. REV. 1385, 14981524 (following Butterfield, supra note 2, in describing Leland's activities in Virginia, and then analyzing in detail several works written by Leland after his return to New England); Edwin S. Gaustad, The Backus-Leland Tradition, 2 FoundaTIONS: A BAPTIST J. OF HIST. \& THEOLOGY 131 (1959) (noting that "[i]n Leland we find a manful gripping of two forces not always readily compatible: rationalism and pietism. However, both granted priority to the individual... Leland, on both counts, as a pietist and as a rationalist, was sincerely respectful of the worth of human personality and gave himself without stinting to its elevation."); Koppelman, supra note 6, at 59-63; Melissa Rogers, Traditions of Church-State Separation: Some Ways They Have Protected Religion and Advanced Religious Freedom and How They Are Threatened Today, 18 J.L. \& POL. 277, 280-94, 283 n.22, 319-20 (discussing "Isaac Backus and John Leland on the limits of civil power"; suggesting at note 22, in a misunderstanding of Butterfield, supra note 2, that Butterfield did not think Leland and Madison met before the Orange County election for the Virginia ratifying convention); J.T. Smith, Life and Times of the Rev. John Leland, 5 BAPTIST Q. 230 (1871), available at http://books.google.com/books? id= NZNLAAAAMAAJ. For purposes of this article, two volumes of James Madison's papers provide important information about Leland's activities, as will be noted below. See 10 The PAPERS OF JAMES MAdison (Robert A. Rutland \& William M. Rachel eds., The Univ. of Chicago Press. 1977); 11 THE PAPERS OF JAMES MADISON (Robert A. Rutland \& Charles F. Hobson eds., The Univ. Press of Virginia 1977).

The index to Hamburger's book notes twenty-seven passages or footnotes that discuss Leland. HAMBURGER, supra note 6, at 504. Hamburger's emphasis on Leland's close relationship with Jefferson is helpful. See, e.g., id. at 156-57, 165-69. But Hamburger's main point with regard to Leland is that even though Leland (and Nehemiah Dodge) came closest among Baptists to accepting Jefferson's notion of separation of church and state, Leland did not, in the end, accept it fully. See id. at 165-70. Hamburger does not stress the implications of Leland's own political activities, though he briefly notes that Leland "in early 1789 , encouraged Baptists to vote for James Madison [for Congress] so that he might propose what became the First Amendment." Id. at 156. 
to be said. ${ }^{13}$ In each case, it could be said that Leland assisted Madison at Madison's request, using his influence as a religious leader to help Madison win the election. That characterization is more clearly appropriate for Madison's election to the First Congress; it could be said, by contrast, that Madison defused organized Baptist opposition to his candidacy to be a delegate to the Virginia ratifying convention. ${ }^{14}$

Of course, the Establishment Clause did not become a part of the Constitution until $1791 ;{ }^{15}$ thus, Leland's actions predated its effectiveness and could perhaps, in theory, have been contrary to its purposes. Consider, however, what Madison's attitude would have been

In his very insightful article, Paul Finkelman stresses the importance of Leland's support for Madison in the election for the Virginia ratifying convention and also the importance of Leland's views in influencing Madison to see the need for a Bill of Rights. Paul Finkelman, James Madison and the Bill of Rights: A Reluctant Paternity, 1990 SuP. CT. REV. 301, 323-24.

For information on Leland's work in New England after he returned there in 1791, see 2 William G. MCLOUghlin, New England DisSENT, 1630-1883: The Baptists AND the SeParation of Church and State (1971); William R. Estep, New England Dissent, 1630-1833: A Review Article, 41 CHURCH HIST. 246, 248-50 (1972), available at http://jstor.org/stable/3164163 (criticizing McLoughlin for minimizing Leland's importance, for not recognizing that "it was John Leland, not Isaac Backus, who played such a decisive role in the formulation of the Constitution's religious liberty provisions," for otherwise minimizing Leland's importance, for arguing that Baptists only "demanded freedom for others when they discovered this was the only way to achieve it for themselves," and for not recognizing that Baptists generally "sought liberty of conscience for all men"); Esbeck, supra, at 1501-24.

Leland has been the subject of several doctoral dissertations and master's theses, which provide useful background information. See, e.g., Martha E. Boland, Render Unto Caesar: Sources of the Political Thought of John Leland (May 1997) (unpublished Ph.D. dissertation, New Orleans Baptist Theological Seminary) (on file with author), available through ProQuest Dissertations and Theses, vol. 0320, issue 0144, p. 174, and available through UMI Microform, UMI Number 9829023; Rosemary Kugler, Elder John Leland: Evangelical minister and republican rhetorician (1992) (unpublished master's thesis, Rice University) (on file with author), available through ProQuest Dissertations and Theses, vol. 0337, issue 0187, p. 150, and available through UMI Microform, UMI Number 1348987.

13. In any event, it is worthwhile, by way of reminder, to highlight Leland's contribution to our heritage of religious freedom. Samuel Johnson and Plato could not both be wrong: "[I]t is not sufficiently considered that men more frequently require to be reminded than informed." 1 SAMUEL JOHNSON, Rambler No. 2, THE RAMBLER 7, 12 (10th ed. London, W. Strahan et al. 1784), available at http://books.google.com/books?id= USUJAAAAQAAJ. "[F]or all enquiry and all learning is but recollection." 2 PLATO, Meno, The Dialogues of Plato Translated into English with analyses and INTRODUCTIONS 27, 40 (B. Jowett ed. \& trans., 3d ed., London, Oxford Univ. Press 1892) (photo. reprint 1931), text available from the Online Library of Liberty at http://oll.libertyfund.org/ (by typing "Plato Meno" in search box and then selecting Dialogues of Plato, volume 2).

14. See infra text accompanying notes $227-329$ (with respect to the Congressional election) and 96-226 (with respect to the ratifying convention election).

15. See, e.g., County of Allegheny v. Am. Civil Liberties Union, 492 U.S. 573, 647 (1989). 
toward the Establishment Clause had its apparent meaning suggested that Leland's efforts, especially his efforts in getting Madison elected to the First Congress, were illegitimate. It is extraordinarily difficult to believe that Madison could have understood the Establishment Clause as creating a wall of separation that would prohibit (or disfavor) the very political activity that had enabled him to win election, serve in the First Congress, and argue for adoption of the Establishment Clause; that is, Leland's political activity in his role as a religious leader, political activity that had been crucial to giving Madison the opportunity to be in Congress and to propose the Bill of Rights. In fact, Leland remained a staunch Jeffersonian Republican (and, later, a Jacksonian Democrat) ${ }^{16}$ his entire life and continued to use his religious influence as a very popular Baptist preacher to advance that party's cause-apparently without any objection from Jefferson, Madison, Monroe, Jackson, or Van Buren-until his death in $1841 .{ }^{17}$ At the very least, Leland's role in

16. See Butterfield, supra note 2, at 214-33. In this article, the term "Republican," rather than "Democratic" or "Democratic Republican," is used to describe the party of Jefferson and Madison, in line with the usage of the time. See, e.g., ALEXIS DE TOQueVIlle, DemOCRACY IN AMERICA 176 (J.P. Mayer ed., George Lawrence trans., HarperPerennial 1988); EdWARd J. LaRson, A Magnificent Catastrophe: THE Tumultuous Election of 1800, America's First Presidential Campaign 4 \& passim (2007); 2 PaGe SMith, John Adams 831 (1962).

The Republican party's success led to its eventual split, with one of the resulting parties becoming today's Democratic party. By 1816 the Federalist party was dying. "In the election of 1816 it made no formal nomination of presidential and vice-presidential candidates, and it put forth electoral tickets in only three states. Four years later it took no part in the election, and only in Pennsylvania and Connecticut were opposing electoral tickets placed before the people." Charles S. Sydnor, The One-Party Period of American History, 51 AM. HIST. REV. 439, 439-50 (1946), available at http://www.jstor.org/stable/ 1840108 (footnote omitted). With John Quincy Adams's election to the presidency by the House in 1824 (even though Andrew Jackson had received a plurality of electoral votes), the Republican party split, with Adams and Henry Clay leading the National Republicans in 1828 against Jackson's Democratic Republicans. See 3 PAGE SMITH, ThE SHAPING OF AMERICA 719-28 (1980); 4 id. at 8-14 (1981); Republican Party (Jeffersonian), CONCISE DiCTIONARY OF AMERICAN HISTORY 815-16 (Wayne Andrews ed., 1962); Democratic Party, id. at 290. "With the name soon abbreviated to Democratic, this party [the Democratic Republicans] became the immediate ancestor of the present Democratic party." Id. By 1836 "[t]he anti-Jacksonians [had] gradually coalesced into an odd assortment of National Republicans, Anti-Masons, and pro-Bank Democrats who denominated themselves Whigs. ..." 4 PAGE SMITH, ThE ShaPING OF AMERICA 124 (1981).

The American Presidency Project at the University of California, Santa Barbara, has a useful interactive web page with information about each presidential election. See http://www.presidency.ucsb.edu/elections.php.

17. The Democrats finally lost the White House in the 1840 election, won by the Whig candidate, William Henry Harrison, who was inaugurated in 1841 , the same year Leland died. On Jan. 6, 1841, Leland wrote:

Gen. Harrison comes into the presidency by an overwhelming majority; of course, the greatest part of the people are pleased. If, as many men believe, the means made use of for his promotion, have been ridiculous, false, and 
furthering the proposal of the Bill of Rights casts doubt on any approach to the Establishment Clause that would limit or discourage participation by religious leaders and religious communities in the political arena.

Although this article will focus on Leland's relationship with Madison in connection with the elections of March 1788 and February 1789 , it is important to note Leland's relationship with Thomas Jefferson as well. Leland indeed was Jefferson's "friend and ally," as Hamburger puts it. ${ }^{18}$ It was, of course, in his famous January 1, 1802 letter to a group of Connecticut Baptists, the Danbury Baptist Association, that Jefferson described the Establishment and Free Exercise Clauses as "building a wall of separation between Church and State."19 Jefferson

deceptive, degrading to any country that looks for respectability, still he is the chosen one. I will acknowledge him. For him I will pray. But whether he is exalted to be a scourge to the United States, or a blessing to the people, I leave for the future historian to say. I am no prophet.

WRITINGS, supra note 12, at 741. Cf. Esbeck, supra note 12, at 1522-23 ("Although Leland fought vigorously against any legislation favoring the church, he had no qualms about a robust involvement of the church or her members in political activity.... This political activity was in full harmony with Leland's policy of employing persuasive power while renouncing legal coercion."); Rogers, supra note 12, at 289 n.48 ("The work and words of Backus and Leland testify to their belief that religious people should be free to try to influence the state.") (noting also Leland's rejection of laws that would prohibit ministers from serving in elective office). Religious persons were not, however, entitled to influence the state into mandating religious practices; thus he opposed Sunday observance laws and even opposed an effort to repeal an Act of Congress that required all post offices to be open for at least an hour every day of the week, including Sundays. See Butterfield, supra note 2, at 236-40; Brad Creed, John Leland and Sunday Mail Delivery: Religious Liberty, Evangelical Piety, and the Problem of a "Christian Nation," 33 FIDES ET HISTORIA, at 1 (Summer/Fall 2001).

18. HAMBURGER, supra note 6 , at 165.

19. See, e.g., Daniel L. Dreisbach, "Sowing Useful Truths and Principles": The Danbury Baptists, Thomas Jefferson, and the "Wall of Separation," 39 J. OF CHURCH \& ST. 455, 468-69 (1997); Daniel L. Dreisbach, Thomas Jefferson, a Mammoth Cheese, and the "Wall of Separation Between Church and State," in RELIGION AND THE NEW REPUBLIC: FAITH IN THE Founding of AMERICA 65, 73-74 (James H. Hutson ed., 2000) (giving the full text of Jefferson's letter). The text of Jefferson's letter is also available from many other sources. See, e.g., 8 Thomas JefFerson, The Writings of Thomas JEFFERSON 113-14 (H.A. Washington ed., Washington, D.C., Taylor and Maury 1854), available at http://books.google.com/books?id=W2UFAAAAQAAJ; MiCHAEL W. MCCONNELl, JoHn H. GaRvey \& ThOMAS C. BeRG, RELIGION AND THE CONSTITUTION 42 (2d ed. 2006); JoHn T. NOONAN, JR. \& EdWARd MCGlynN GafFney, JR., Religious FREEDOM: HISTORY, CASES, AND OTHER MATERIALS ON THE INTERACTION OF RELIGION AND GOVERNMENT 205-06 (2001). Hamburger states that in the Sowing Useful Truths article "Dreisbach provides by far [the] most accurate transcript" of Jefferson's letter and related documents. HAMBURGER, supra note 6 , at $1 \mathrm{n} .1$. In the letter's second paragraph, Dreisbach's transcript departs from the other versions by replacing "legislative powers" with "legitimate powers" and italicizing the word "their" in the phrase "their legislature." Dreisbach also replaces the word "and" in several places with ampersands and provides what he views as the original capitalization (or lack thereof). As Hamburger also notes, "[t]o Dreisbach's work James H. Hutson adds an infrared photograph that reveals the deleted words in Jefferson's letter." HAMBURGER, supra note 6, at 1 n.1 (citing James H. 
certainly was displeased with the religious attacks made on him during the 1800 election by representatives of the Congregationalist "standing order" in Connecticut and elsewhere in New England. ${ }^{20}$ But that same day, New Year's Day, 1802, Jefferson welcomed Leland, a very politically active religious leader, to Washington. ${ }^{21}$ Leland had led the delegation that brought Jefferson the 1,235 pound "Mammoth Cheese" produced in Massachusetts from the milk of good Republican cows. ${ }^{23}$ Leland had preached all along the way. ${ }^{24}$

"Two days later, at the President's invitation, [Leland] preached before both houses of Congress on the text 'Behold a greater than Solomon is here. ${ }^{[25], 26}$ It seems that Sunday worship services had been

Hutson, Thomas Jefferson's Letter to the Danbury Baptists: A Controversy Rejoined, 56 WM. \& MARY Q. 779 (1999)). Two handwritten versions of the letter (one "digitally revised to expose obliterated sections") are available at http://memory.loc.gov/ammem/ collections/jefferson_papers/mtjtime $3 \mathrm{c}$.html.

20. See, e.g., LARSON, supra note 16, at 167-74; L. Scott Smith, Religion, Politics, and the Establishment Clause: Does God Belong in American Public Life?, 10 CHAP. L. REV. 299, 308-09 (2006); Elizabeth G. Myers, Note, Timing Is Everything: The Social Context Behind the Emergence of Separation Ideology During the Presidential Campaign of 1800, 83 TEX. L. REV. 933 (2005).

21. HamBurGer, supra note 6, at 156; Butterfield, supra note 2, at 223-25; Dreisbach, Thomas Jefferson, supra note 19, at 66. In another article, Daniel Dreisbach and John Whaley suggest that the public attention given to the cheese as it neared Washington, and the festivities at the White House when it arrived, may have influenced Jefferson's writing of the letter to the Danbury Baptists:

Given the spectacle created by the mammoth cheese, this event was undoubtedly on Jefferson's mind as he drafted the Danbury letter. Added to the impact of the cheese's arrival was the presence of John Leland, the man who had supported Jefferson so steadfastly in Virginia during his battle to enact the "Statute for Establishing Religious Freedom." It would seem, therefore, that while Jefferson was responding to the Danbury Baptists' views on church-state relations, Jefferson must also have been thinking about his life-long commitment to church-state separation, and the battles he had fought to establish this principle in Virginia.

Daniel L. Dreisbach \& John D. Whaley, What the Wall Separates: A Debate on Thomas Jefferson's "Wall of Separation" Metaphor, 16 CONST. COMMENTARY 627, 641-42 (1999).

22. Butterfield, supra note 2, at $220,227$.

23. HAMBURGER, supra note 6, at 156 (" $[\mathrm{N}]$ o contribution was taken from the cows of Federalists."). But see Butterfield, supra note 2, at 220 ("Local histories add a good many details about the production of the Cheese that may or may not be accurate. It is said, for example, that no Federalist cows were allowed to contribute milk."). For another account of the "mammoth cheese," see 4 DUMAS MALONE, JEFFERSON THE PRESIDENT 106-08 (1970) (stating that the cheese was made "reputedly from the milk of 900 cows at one milking, not one of them a Federalist" and noting that the affair "may be described as a highly effective publicity stunt").

24. Events, supra note 1, at 32.

25. The Biblical text, from the King James (or Authorized) Version, is found in two of the Gospels, in Matthew 12:42 and Luke 11:31. The verse reads: "The queen of the south shall rise up in the judgment with [the men of] this generation, and shall condemn $\underline{\text { it }}$ [them]: for she came from the uttermost [utmost] parts of the earth to hear the wisdom 
held regularly in the House chamber since December $1800,{ }^{27}$ but Jefferson apparently had not previously attended, ${ }^{28}$ at least not since becoming President. ${ }^{29}$ James Hutson argues that Jefferson saw the presence of "[o]ne of the nation's foremost advocates of religious freedom," the "famous Baptist preacher, John Leland" in Washington, as the solution to a problem: how to "persuade New England Republicans and ordinary Federalists everywhere that he was a friend of religion and thus a respecter of their fundamental values." ${ }^{30}$ In Hutson's view, "Jefferson perceived that participating in divine services in one of the nation's most visible public places with one of its most celebrated

of Solomon; and, behold, a greater than Solomon is here." (The bracketed language appears only in Luke; the underlined and italicized language appears only in Matthew.) The reference clearly is to Jesus as the one who is greater than Solomon. The audacity of Leland's application of the verse to Jefferson helps to explain the offense taken by a Federalist member of Congress, who was a Congregationalist minister. See Butterfield, supra note 2, at 226-27.

26. Hatch, The Democratization of Christianity and the Character of American Politics, supra note 12 , at 110 ; HATCH, THE DEMOCRATIZATION OF AMERICAN CHRISTIANITY, supra note 12, at 96; MALONE, supra note 23, at 108 . Only Hatch (of sources located by the author) states that Jefferson invited Leland to preach, and Hatch does not provide any authority for his assertion. It seems likely, though, given Leland's past connections with Virginia and with Jefferson's efforts to protect religious liberty. It is especially likely if James Hutson is right that Jefferson saw Leland's presence in Washington as the solution to a problem, as noted in the text below at note 31 .

27. See The Debates and Proceedings in the Congress of the United States, Sixth CONGRESS 798 (Washington, Gales \& Seaton 1851) (Dec. 4, 1800) ("The SPEAKER informed the House that the Chaplains had proposed, if agreeable to the House, to hold Divine services every Sunday in their Chamber."), available at http://books.google.com/books?id=4SxOAAAAMAAJ. The Speaker's statement is cited by the sponsor of a recent House resolution for the proposition that "in 1800 , Congress approved the use of the just-completed Capitol structure as a church building, with Divine services to be held each Sunday in the Hall of the House." See Final Footnoted Version of H.R. Res. 888, 110 th Cong. (2007) ("Affirming the rich spiritual and religious history of our Nation's founding and subsequent history and expressing support for designation of the first week in May as 'American Religious History Week' for the appreciation of and education on America's history of religious faith."), available at http://forbes.house.gov/uploadedfiles/HRES888_Final\%20Footnoted\%20Version.pdf.

By the time of the January 3, 1802 worship service, the House was meeting in its new temporary south wing chamber (nicknamed the "Oven") instead of where it had been meeting, in the second floor library in the north (Senate) wing of the Capitol. See William C. AlLEN, History OF THE United STATES CAPITOL 44-46 (2001), available at http://www.gpo.gov/congress/senate/capitol/pg3.pdf.

28. See HAMBurger, supra note 6 , at 162 (quoting JAMES M. HutSON, RELIGION AND THE FOUNDING OF THE AMERICAN REPUBLIC 93 (1998)).

29. See James H. Hutson, Thomas Jefferson's Letter to the Danbury Baptists: A Controversy Rejoined, 56 WM. \& MARY Q. 779, 786 (1999) (noting that Jefferson often had attended religious services in Virginia in public buildings and quoting a letter from the Senate chaplain stating that Jefferson had attended services in the Capitol when Vice President during the preceding congressional session).

30. Id. at 785 . 
preachers would be a public relations bonanza., ${ }^{, 31}$ Jefferson therefore attended Leland's service and then proceeded to attend services regularly in the House (and to permit other federal buildings to be used for services). ${ }^{32}$ If that was Jefferson's intent, he seems to have succeeded, but Hutson nevertheless defends Jefferson against charges of hypocrisy, noting that Jefferson had attended worship services in public buildings before becoming President, both in Washington and in Virginia. ${ }^{33}$

It is also important to note that Leland's work for religious freedom did not end with Madison's election to the First Congress in February of $1789 .^{34}$ Lyman Butterfield, an editor of both Thomas Jefferson's papers and the papers of the Adams family, assessed Leland's life work for religious freedom by writing that Leland

played a substantial part in molding [an] American tradition that is full of meaning to all of us today - the separation of church and state in the United States. ... In 1774, when Leland was converted to the Baptist faith, the Baptists were generally regarded as a set of ignorant enthusiasts, without social standing, without legal sanction for their religious services or for marriages performed by their ministers. In Virginia Baptist preachers were being regularly thrown into prison as strollers and vagabonds; mob actions breaking up their services went unpunished by the magistrates; their petitions to the legislature for relief from these oppressions were largely disregarded. In Massachusetts and Connecticut Baptists were fined and their property was distrained for taxes to pay Congregational ministers whose teachings were repugnant to them, and to build and repair meeting houses they would not attend. Much of Leland's sixty-seven year career as a Baptist evangelist was expended in fighting to remove these disabilities - not only for Baptists but for persons of all faiths, Christian and non-Christian, and even for those who held no recognized religious faith. When he died the battle for complete religious freedom in the United States had been very largely won, though this was not a battle in which there could ever be a final victory. ${ }^{35}$

Noting Leland's commitment to rights of conscience for all, Bishop Thomas Curry, most recently the author of Farewell to Christendom:

31. Id. at $785-86$.

32. Id.

33. Id. at 785 ("As Jefferson anticipated, his participation in public worship in the House was widely reported in the nation's newspapers. ... In presenting Jefferson to the nation as a churchgoer, this publicity appears to have offset the negative impression created by his refusal to issue religious proclamations. ..."); id. at 786-89.

34. See Butterfield, supra note 2, at 196-240.

35. Id. at 156-57. 
The Future of Church and State in America, ${ }^{36}$ gives Leland high praise. Curry explains Leland's view on laws allowing only dissenting Protestants to be exempted from taxation to support the established church. Leland believed such laws

were unjust because "heathens, deists, and Jews are not indulged," and [Leland] asked if a Jew should have to support the "religion of Jesus Christ, when he really believes that he was an impostor? Must the Papist be forced to pay men for preaching down the supremacy of the Pope, who they are sure is the head of the Church?"

... Others in America at the time would have agreed with Leland's opposition to establishment of religion; but no religious figure would have transcended his contemporary cultural milieu and followed the logic of his thought to such sympathetic imaginative conclusions. Indeed, until Leland no religious thinker matched the thought on Church and State of Roger Williams of the previous century. ${ }^{37}$

36. Thomas J. Curry, Farewell to Christendom: The Future of ChurCh AND STATE IN AMERICA (2001).

37. Thomas J. Curry, The First Freedoms: Church and State in america to the Passage of The First Amendment 182 (Oxford University Press 1986) (paperback edition) (quoting The Rights of Conscience Inalienable, and, Therefore, Religious Opinions Not Cognizable by Law; or, The High-Flying Churchman, Stripped of his Legal Robe, Appears a Yaho[o], in WRITINGS, supra note 12, at 177, 187 (1791)). Michael McConnell gives Leland pride of place:

The paradox of the religious freedom debates of the late eighteenth century is that one side employed essentially secular arguments based on the needs of civil society for the support of religion, while the other side employed essentially religious arguments based on the primacy of duties to God over duties to the state in support of disestablishment and free exercise. It was Baptist preacher John Leland who first stated that "[t]he notion of a Christian commonwealth, should be exploded forever."

Michael W. McConnell, The Origins and Historical Understanding of Free Exercise of Religion, 103 HARV. L. REV. 1409 (1990) (footnote omitted) (quoting JOHN LELAND, The Virginia Chronicle, in WRITINGS, supra note 12, at 92, 107 [hereinafter Virginia Chronicle]) (also noting, at 1499, that "the Baptists and other proponents of religious liberty in America did not adopt Locke's position [of no religious exemptions from the law] because they insisted on defining liberty of conscience as adherence to the demands of God"); see also Steven D. Smith, The Rise and Fall of Religious Freedom in Constitutional Discourse, 140 U. PA. L. REV. 149, 158 (1991) ("In view of this broadly religious framework, it is not surprising that the religious justification for religious freedom had great force in the colonial and founding periods. The argument was eloquently advanced by ministers and religious leaders such as Roger Williams, William Penn, John Leland, and Isaac Backus."). For a different view of Leland's approach, see Noah Feldman, The Intellectual Origins of the Establishment Clause, 77 N.Y.U. L. REv. 346, 387 (2002) (footnotes omitted):

John Witte, Jr.'s treatment of the Baptist position quotes John Leland, "the fiery Baptist preacher," as saying "bluntly" that "[t]he notion of a Christian commonwealth should be exploded forever." Witte implies that this view was distinctively evangelical. Yet in making this statement, the Baptist itinerant 
The author hopes that this article will create greater awareness of John Leland, of his fascinating life, of the important role he played in our constitutional history, of his commitment to religious liberty for all, of his faith, of his humor, of his criticism of slavery, ${ }^{38}$ and of his engaging,

Leland was doing no more than echoing Locke's statement that "there is absolutely no such thing, under the Gospel, as a Christian commonwealth." The statement is thus not particularly unique to an evangelical perspective on liberty of conscience.

In fact, John Leland's argument for religious liberty followed straightforwardly Lockean lines. ...

Frank Lambert suggests that Leland "based his views of religious liberty on biblical principles and the Lockean idea of the social compact." FranK LAMBERT, THE Founding Fathers and the Place of Religion in America 285 (Princeton University Press 2003) (emphasis added).

38. For example, in 1790 the Virginia Baptist General Committee (which had been formed in 1783 and given the task of "consider[ing] all the political grievances of the whole Baptist Society in Virginia" and the exclusive role of presenting any "petition, memorial, or remonstrance" on behalf of any Baptist Association to the state's General Assembly) was unable to agree on a resolution concerning slavery and thus asked Leland to draft a resolution, which he did:

Resolved, That slavery is a violent deprivation of the rights of nature and inconsistent with a republican government, and therefore recommend it to our brethren to make use of every legal measure to extirpate this horrid evil from the land; and pray almighty God that our honorable Legislature may have it in their power to proclaim the great Jubilee, consistent with the principles of good policy.

Robert B. SEMPle, A History of THE Rise ANd Progress of the BAPTISTS IN Virginia 95, 105 (1894 ed. revised and extended by G.W. Beale), available at http://books.google.com/books?id=t6RhTC8ziQQC. See Butterfield, supra note 2, at 181-82 (noting that this took place in 1790 rather than, as Semple wrote, 1789); Virginia Chronicle, supra note 37, at 92, 113 (noting formation of Baptist General Committee in October, 1783); see also Bruce Gourley, John Leland: Evolving Views of Slavery, 1789 1839, 40 BAPTIST HIST. AND HERITAGE 104 (2005). Leland also wrote forcefully in favor of religious freedom for slaves. See, e.g., Virginia Chronicle, supra note 37, at 95 ("Liberty of conscience, in matters of religion, is the right of slaves, beyond contradiction; ... ."); Kurt T. Lash, The Second Adoption of the Establishment Clause: The Rise of the Nonestablishment Principle, 27 ARIz. ST. L.J. 1085, 1137 n.233 (1995). One writer suggests Leland left Virginia to return to New England "in large part because of the intransigence of the people on slavery." Douglas Ambrose, Of Stations and Relations: Proslavery Christianity in Early National Virginia, in RELIGION AND THE ANTEBellum Debate OVER Slavery (John R. McKivigan \& Mitchell Snay eds., 1998) 35,59 endnote 19. Leland's parting address on leaving Virginia was particularly eloquent, noting that he could not "endure to see one man strip and whip another, as free by nature as himself, without the interference of a magistrate, or any being or thing to check his turbulent will." JOHN LELAND, Letter of Valediction, on Leaving Virginia, in 1791, in WRITINGS, supra note 12, at 171. And Leland described slavery as "in its best appearance ... a violent deprivation of the rights of nature, inconsistent with republican government, destructive of every humane and benevolent passion of the soul, and subversive to that liberty absolutely necessary to ennoble the human mind. . ." Id. at 174. Leland said he hoped to meet many of the slaves among his listeners in heaven and urged his hearers (whites at least) to pray for the freedom of the slaves; but he also counseled the slaves to be more diligent in obeying their masters, stated that masters had the right to discipline slaves, and asked the slaves to be "patient in their hardships" until 
plain-spoken manner of communicating. His writings will reward study, and the reader is likely to enjoy the effort. As Butterfield says,

In the long fight he waged Leland showed great tenacity of purpose and real intellectual breadth. He had still other commendable qualities, among them a gift of humor which endeared his audiences to him and which distinguishes his published writings from the great mass of religious and political oratory of the time. ${ }^{39}$

Not surprisingly, the 1845 compilation of Leland's writings (The Writings of the Late Elder John Leland ${ }^{40}$ ) is difficult to find in hard copy, and the 1969 and 1986 reprints are out of print, but in December 2006 it was scanned and digitized for viewing and download on Google Books. ${ }^{41}$ Thus the book is now very easily accessible. Readers should not pass up the opportunity to get to know "Jefferson's friend and ally, the irrepressible John Leland. ${ }^{.42}$

\section{HISTORICAL BACKGROUND}

John Leland was born in 1754 in Grafton, Massachusetts, near Worcester and "about 40 miles west of Boston."43 His parents were Congregationalists, though his father had some Baptist leanings. ${ }^{44}$ In 1772 , at the age of eighteen, Leland began to have a strong religious

freedom should come. Id. at 174 . One of the slave owners-Robert Carter-apparently was so moved that over time he freed 422 of his slaves in family groups. MECHAL Sobel, Trabelin' On-The Slave Journey to an Afro-BAPTIST Faith 86-87 (1988); see also Mechal Sobel, The World They Made Together: Black and White VAlues IN EIGHTEENTH-CENTURY VIRGINIA 299-300, endnote 69 (noting that "Robert Carter III's Day Book includes a transcription of a Leland sermon on slavery" and also noting that Carter's children may have tried to prevent some of the manumissions).

39. Butterfield, supra note 2, at 157-58.

40. WRITINGS, supra note 12. As of August 13, 2008, only one copy of any version of the book was for sale on Amazon.com (the out-of-print 1969 photographic reprint at a price of \$378). The OCLC WorldCat database of all items catalogued by the roughly 69,000 OCLC member libraries worldwide (see http://www.oclc.org/about/default.htm) shows only thirty-one who have the 1845 edition, plus 165 who have the 1845 edition in a microform version (which your author found very difficult to read), 211 who have the 1969 reprint (entitled THE WRITINGS OF JOHN LELAND, omitting "Late Elder"), and twenty who have the 1986 reprint. WorldCat is accessible from book.google.com search pages by clicking on the "Find this book in a library" link (in addition to being accessible through various institutional affiliations).

41. See http://books.google.com/books?id=bMAiAAAAMAAJ (noting that the New York Public Library's copy of the book was digitized December 14, 2006). Google Books provides what is, in essence, a very readable photoreproduction of the book that can be read on line (with full text searching) or downloaded (as a pdf image file).

42. HAMBURGER, supra note 6 , at 165 .

43. Events, supra note 1 , at 9.

44. William B. Sprague, Annals of the American Baptist Pulpit 174 (New York, Robert Carter \& Bros. 1860), available at http:/books.google.com/books?id= Oh47AAAAIAAJ; Gaustad, supra note 12, at 132; see also Events, supra note 1, at 9. 
experience, which led him to attend Baptist meetings, ${ }^{45}$ and which culminated two years later in his becoming assured that he had been, in Baptist terminology, "converted" or "saved."46 From the beginning of the experience, he had felt a call to preach, and he felt impelled to do so even before he was sure that he had been converted. ${ }^{47}$ Leland later wrote that, in 1774, "I finally surrendered, and devoted my time and talents to the ministry, without any condition, evasion, or mental reservation." He began his preaching ministry, and in October, 1775, set out on an eight-month preaching tour to Virginia and back. ${ }^{49}$

At almost exactly the same time, James Madison (who was three years older than Leland ${ }^{50}$ ) was beginning his fight to enshrine religious liberty in Virginia law. ${ }^{51}$ Madison succeeded in having the language of the proposed Virginia Declaration of Rights changed, so that instead of providing for enjoyment of "the fullest toleration in the exercise of religion," it provided, as finally adopted on June 12, 1776, for enjoyment "equally" of "free exercise of religion."

45. In particular he was influenced by the preaching of a twenty-one year old Baptist evangelist, Elhanan Winchester, Events, supra note 1, at 11, who later became "the most wide-ranging and successful 18th century American Universalist evangelist." DICTIONARY OF UNITARIAN AND UNIVERSALIST BIOGRAPHY, Elhanan Winchester, http://www25.uua.org/uuhs/duub/articles/elhananwinchester.html (last visited Aug. 3, 2008).

46. Events, supra note 1, at 10-18; Butterfield, supra note 2, at 160-61.

47. Events, supra note 1, at 10-18. Such preaching could have a powerful effect on hearers. "John Leland's words describing the 'power of the gospel in the hand of the spirit' are especially dramatic: the word of God 'tears off the veil of the heart-rends the stupor from the conscience-removes the film from the eye of the soul. ..." Kathleen A. Brady, Foundations for Freedom of Conscience: Stronger than You Might Think, 10 ROGER Williams U.L. REv. 359, 376 n.66 (2005) (quoting from JOHN LELAND, Sermon Preached at Ankram, Dutchess County, N.Y., at the Ordination of Rev. Luman Birch, in WRITINGS, supra note 12, at 301, 305 (1806)).

48. Events, supra note 1, at 18.

49. Id. at 19.

50. See 1 Irving Brant, James Madison: The Virginia Revolutionist 29-30 (Bob's Merrill Company 1950) (noting that Madison was born on March 5, 1750 under the Old Style (Julian) calendar but on March 16, 1751 under the New Style (Gregorian) calendar, which was adopted by the British empire that same year).

51. See, e.g., Daniel L. Dreisbach, Church-State Debate in the Virginia Legislature: From the Declaration of Rights to the Statute for Establishing Religious Freedom, in Religion and Political Culture in JefFerson's Virginia 135, 138 (Garrett W. Sheldon \& Daniel L. Dreisbach eds., 2000).

52. Virginia Declaration of Rights, IXVI (1776), available at http://www.yale.edu/ lawweb/avalon/virginia.htm (emphasis supplied); MCCONNELL, supra note 19, at 45-46 (noting that 'Madison objected to the word 'toleration' on the ground that it implied legislative grace"); Robert S. Alley, The Despotism of Toleration, in JAMES MADISON ON RELIGIOUS LIBERTY 142, 147 (Robert S. Alley ed., 1985); Butterfield, supra note 2, at 173-74 (stating that "Madison's alteration was of great and immediate significance, for while toleration implies a favor granted, equality recognizes an inalienable right"). How did it happen that Madison was a member of the Virginia convention that adopted the 
On September 30, 1776, a few months after returning to Massachusetts from Virginia, Leland married Sally Devine "and immediately started with her to Virginia." 53 He became a preacher at a church in Culpeper County, Virginia, ${ }^{54}$ and made a preaching journey to South Carolina. ${ }^{55}$ In 1778 , the Lelands moved to Orange County, Virginia, ${ }^{56}$ site also of James Madison's home, Montpelier. ${ }^{57}$ Orange County would be Leland's home base for thirteen years, ${ }^{58}$ as he continued to preach in many places locally, to make long preaching journeys, to start churches, and to serve as pastor of a church in nextdoor Louisa County. ${ }^{59}$ Leland later said that, since beginning his

Declaration of Rights? He "was elected a delegate to the Virginia Convention in 1776 with the help of the Orange County Baptists." Mark A. Beliles, The Christian Communities, Religious Revivals, and Political Culture of the Central Virginia Piedmont, 1737-1813, in Religion and Political Culture In JefFerson's Virginia 3, 20 (Garrett W. Sheldon \& Daniel L. Dreisbach eds., 2000).

53. Events, supra note 1, at 19.

54. Leland frankly states that his work at the Mount Poney church in Culpeper County "was not a blessing to the people." He had been ordained by the church but not by a group (a "presbytery") of ministers, an example of his refusal to conform to traditions that, in this case, meant he was not recognized as a pastor ("fellowshipped") by other area Baptist churches (but that does not mean they had any problem with him being an itinerant preacher). "I was too young and too roving to be looked up to as a pastor. Difficulties arose, the church split, and I just obtained a dismission and recommendation. God had another man for Mount Poney church. William Mason became their pastor, and he has done wonders in the name of Jesus." Id. Leland was not ordained by a presbytery until some time in June, 1787. Id. at 26.

55. Id.

56. Id.

57. See, e.g., RICHARD LABUNSKI, JAMES MADISON AND THE STRUGGle FOR THE BILL OF Rights 134 (Oxford University Press 2006).

58. Events, supra note 1, at 19.

59. Id. at 19-29; SEMPLE, supra note 38, at 215-17 (stating that Leland became pastor of "Thompson's church" (later known as Goldmine church) in Louisa County, after the departure of pastor David Thompson for Kentucky); see also MaLCOLM H. HARRIS, History OF LOUISA COUNTY 193-94 (1936) (noting that Leland succeeded Thompson as pastor of the "Lower Goldmine" church, which was the oldest Baptist church in Louisa County). It is not clear when Thompson left his church in Louisa County, but it must have been by 1785 , when he is reported to have helped found a Baptist church in Kentucky. See William D. Nowlin, KentucKY Baptist History1770-1922 37-38 (1922), http://www.geocities.com/baptist_documents/nowlin.ky. baptist.hist.html (select Chapter 3-The First Churches Constituted-1781, and scroll to page 37); William M. Pratt, The Early Baptist Churches of Kentucky (1887), http://www.geocities.com/baptist_documents/kent.early. hist.pratt.html; (scroll down to eleventh paragraph). These documents are published on the Baptist History Homepage after having been rekeyed and formatted in html. See James R. Duvall, Introduction to Baptist History Homepage, http://www.geocities.com/baptist_documents/index.page. introduction.html. A family history records that Thompson (spelled "Thomson" in the family history) left for Kentucky in 1778. SARAH TRAVERS LEWIS (SCOTT) ANDERSON, Lewises, MERIWETHERS AND THEIR KIN 242 (Genealogical Publishing Co., Inc., Baltimore 1984). However, the family history cites as its authority "Semple's Virginia Baptist Ministers," and your author has been unable to confirm that such a work exists. 
preaching ministry, he had "travelled distances, which, together, would form a girdle nearly sufficient to go round the terraqueous globe three times." 60 Whether he in fact traveled almost 72,000 miles on his preaching journeys is not clear, but he certainly traveled a great deal. From Virginia his travels took him north to Philadelphia, where he preached on the street because the Hall of the University held only 200 people, to New England, throughout Virginia, and south to both North and South Carolina. ${ }^{61}$ In Virginia he became, "as an authoritative early Baptist historian wrote, 'probably the most popular [preacher] of any who ever resided in this State."

Madison's (and, of course, Thomas Jefferson's) work for religious liberty was of critical importance to Leland and other Baptists, who were dissenters from the established church (both in New England with its Congregationalist "Standing Order" and in Virginia with its Anglican or Episcopal established church). ${ }^{63}$ Baptists sometimes could not qualify for exemption from religious taxes, or refused to apply for the certifications that would entitle them to exemption; ${ }^{64}$ the result at times was that Baptists' property was seized for nonpayment of taxes levied to

60. Events, supra note 1, at 35 .

61. Id. at 19-29.

62. Butterfield, supra note 2, at 161 (quoting SEMPLE, supra note 38, at 206-07) (bracketed word added by Butterfield).

63. Baptists do not believe that infants should be baptized; rather, Baptists believe that a person should be baptized only after he or she is a believer in the Christian faith, and that baptism should be by immersion, rather than by "sprinkling." See, e.g., JoHN LELAND, The Bible Baptist, in WRITINGS, supra note 12, at 78, 87, \& passim (date unknown but published before 1790 per WRITINGS at 78). Baptists also have a view of the role of government-that the government should not require citizens to conform in matters of religion-that "flatly contradict[s] the assumptions on which the Puritan theocracy in Massachusetts rested." Butterfield, supra note 2, at 164. Those views, and other theological differences with Congregationalists, made Baptists dissenters in New England. For example, in 1644 Massachusetts enacted a statute providing for banishment of those who opposed infant baptism. See WILLIAM HENRY BRACKNEY, THE BAPTISTS 91-92 (1988); ISAAC BACKUS, CHURCH HISTORY OF NEW ENGLAND FROM 1620 TO 1804 52-53 (Philadelphia, King \& Baird 1844), available at http://books.google.com/ books?id=9FIJAAAAIAAJ. Baptists also believe that local congregations should be selfgoverned and not controlled by any broader church hierarchy. See, e.g., LELAND, The Government of Christ a Christocracy, in WRITINGS, supra note 12, at 273, 275 (1804) ("[A]s far as church government on earth is the government of Christ, it is of democratical genius. Church government is congregational, not parochial, diocesan, nor national. Each congregated church disclaims the power of Popes, kings, bishops, parliaments, kirks, or presbyteries, and claims the right and power to govern itself according to the laws of Christ."). Thus, Baptists' views were even more in dissent in Virginia and other southern states with hierarchical Anglican or Episcopalian establishments.

64. See Butterfield, supra note 2, at 165. 
support the established religion. ${ }^{65}$ Of course, itinerant Baptist preachers often did not have their own regular places for holding services; in Virginia, the lack of such places and other onerous requirements sometimes prevented them from obtaining the required license to preach, ${ }^{66}$ even if they tried to obtain licenses, which they often refused to do. $^{67}$ Growing up in Virginia with his father being one of the local Anglican vestrymen (though not one hostile to Baptists), Madison would have been aware of this persecution. ${ }^{68}$ As a young man in 1772,

65. For example, from 1763-1771, Baptists in Ashfield, Massachusetts had their land taken by distraint and sold (usually for much less than its value) to pay religious taxes. 1 McLoughlin, supra note 12, at 531-46. As Butterfield describes it, even though they "already had a meeting house, their lands had been seized and sold in an insulting, unchristian \& ... offensive manner' when they refused to pay taxes for building a Congregational meeting house." Butterfield, supra note 2, at 167 (omission by Butterfield) (quoting AlvaH Hovey, A MEMOIR OF THE LIFE AND Times OF THE REV. ISAAC BACKUS ch. XV (Boston, 1858), available at http://books.google.com/books? id= BcPDDmFqB04C); see also BACKUS, supra note 63, at 190-91 (noting 398 acres were taken from the Ashfield Baptists).

For descriptions of the difficulties faced by Baptists in Virginia, see SEMPLE, supra note 38, at 29-54; Virginia Chronicle, supra note 37, at 105-07. The Virginia legislature suspended state payment of salaries of Anglican ministers in 1776; three years later the legislature repealed the laws providing for such salaries. SEMPLE, supra note 38, at 51 . Thus, from 1776 on, taxes were not assessed to pay ministers. (For a discussion of the 1784-85 religious assessment controversy in Virginia, see infra text accompanying notes 76-86.)

Baptists in New England continued long after 1776 to suffer due to refusal to pay taxes for support of religion. See, e.g., 1 MCLOUGHLIN, supra note 12, at 636-59 (discussing cases in Massachusetts from 1782 to 1810). For extensive description of the Baptists' difficulties in New England, see MCLoughLIN, supra note 12 (both volumes).

66. See, e.g., Virginia Chronicle, supra note 37, at 106 (noting that under Act of Toleration, some Baptist preachers might obtain "license to preach at certain stipulated places; but if they preached at any other places, they were exposed to be prosecuted" (footnote omitted)); William L. Lumpkin, Baptist Foundations in the South: Tracing through the Separates the Influence of the Great Awakening, 1754-1787 110 (1961), reprinted in COLONIAL BAPTISTS AND SOUTHERN REVIVALS: AN ORIGINAL ANTHOLOGY (1980) (describing difficulties faced even by nonitinerant Baptist preachers in obtaining licenses and noting that most such preachers refused to apply for licenses, because "[t]hey considered it no business of the state who should or should not preach").

67. See supra note 66; Butterfield, supra note 2, at 172.

68. See 1 BRANT, supra note 50, at 51-52, 70. Brant explains:

At the time Madison made the choice [in 1769 to attend Princeton rather than William and Mary], a decade of violent persecution of Virginia Baptists was at its midway point. Baptist preachers had been stoned out of Culpeper County in 1765 and jailed in Spotsylvania County in 1768, but they preached unmolested in that part of the adjacent county of Orange where the Madison influence was strongest. ... If Madison's lifelong championship of the religious rights of the Baptists had its origin in what he first witnessed of their troubles, it would have been a logical factor in the decision to attend a college devoted to religious freedom. Evidence is lacking that James Madison, Sr., ever actively supported the rights of dissenters, but he was not looked upon by them as unfriendly.

Id. at 70 (footnote omitted). 
Madison "criticized the harassment and imprisonment in Culpeper and Orange counties of Baptist clergymen who had preached without a license." $\mathrm{He}$ expressed his detestation of "[t]hat diabolical Hell conceived principle of persecution" that "vexe[d] [him] the most of any thing whatever." $" 70$ This sentiment does not seem to have been an isolated expression of opinion by the young Madison, because he added that "I have neither patience to hear talk or think of any thing relative to this matter, for I have squabbled and scolded[,] abused and ridiculed so long about it." $" 71$

Although they had a personal stake in Madison's and Jefferson's work, Leland and other Baptists did not seek religious freedom only for themselves. ${ }^{72}$ Consider, for example, Leland's later criticism of the religious establishment provisions of the 1780 Massachusetts Constitution:

We may next observe, that the legislature of Massachusetts have not power to provide for any public [religious] teachers, except they are Protestant. Pagans, Turks, and Jews, must not only preach for nothing; but Papists, those marvellous Christians, cannot obtain a maintenance for their preachers by the laws of their commonwealth. Such preachers must either be supported voluntarily, support themselves, or starve. Is this good policy? Should one sect be pampered above others? Should not government protect all kinds of people, of every species of religion, without showing the least partiality? Has not the world had enough proofs of the impolicy and cruelty of favoring a Jew more than a Pagan, Turk, or Christian; or a Christian more than either of them? Why should a man be proscribed, or any wife disgraced, for being a Jew, a Turk, a Pagan, or a Christian of any denomination, when his talents and veracity as a civilian, entitles him to the confidence of the public. ${ }^{73}$

69. LABUNSKI, supra note 57 , at 162 . For a description of the persecution, see Lumpkin, supra note 66 , at $110-13$.

70. MCCONNELL, supra note 19, at 16 (quoting Madison's Jan. 24, 1774 letter "to his college friend, William Bradford").

71. Id. For a discussion of Madison's correspondence with Bradford on the subject of religious freedom, see Alley, supra note 52, at 145-46 (quoting from correspondence, excerpts of which are reprinted in the same book (JAMES MADISON ON RELIGIOUS LIBERTY (Alley ed.)) at 44-50). It appears that Madison took steps to help imprisoned Baptists. See Beliles, supra note 52, at $36 \mathrm{n} .112$.

72. For slightly differing points of view on whether Baptists generally were supportive of religious freedom for others on a principled basis, see MCLOUGHLIN, supra note 12, and Estep, New England Dissent, supra note 12. No one doubts (as far as the author is aware) Leland's principled commitment to religious freedom for all.

73. JOHN LELAND, The Yankee Spy: Calculated for the Religious Meridian of Massachusetts, But Will Answer for New Hampshire, Connecticut, and Vermont, Without any Material Alterations, By Jack Nips, in WRITINGS, supra note 12, at 213, 223-24 (1794) [hereinafter Yankee Spy]. The description of Catholics as "marvellous" probably 
Thus the Baptists' support for Jefferson's and Madison's efforts was more than a tactical alliance.

Leland arrived in Virginia too late to be involved with Madison in the hammering out of the 1776 Virginia Declaration of Rights, but it seems likely that Leland quickly learned of his neighbor's key role in advancing religious liberty. Leland became acquainted with Madison's father (James Madison, Sr.) no later than $1781 .^{74}$ It seems highly unlikely that a key Baptist leader in Madison's county would not have noticed Madison's activities on behalf of religious liberty ${ }^{75}$ especially given that Madison "took the lead" in the Virginia legislature in 1784 in opposition to Patrick Henry's bill for a religious assessment, ${ }^{76}$ a bill that

did not mean that he thought they were "splendid" (in the current colloquial sense of "marvelous"); probably it was a reference to Catholic belief in "marvels"-miraclesassociated with saints. See, e.g., Letter of April 15, 1857 from the Hon. G.N. Briggs, Governor of the State of Massachusetts, in SPRAGUE, supra note 44, at 177, 181 (noting that Leland refused to give a supernatural interpretation to a very unusual event and stating, "I think I can say that I never knew a person less given to the marvelous than Elder Leland"). Melissa Rogers notes that although New England Baptist leader Isaac Backus "sometimes used ugly terms to describe his disagreement with Catholics ..., Leland expressed an admirable sense of good will toward Catholics and members of other faith groups that were not popular at the time, as well as a broad defense of their equal rights to religious freedom." Rogers, supra note 12, at 293 (footnote omitted). Rogers also (id. at 290-91) aptly directs our attention to another portion of Yankee Spy (a portion also highlighted by Butterfield, supra note 2, at 209-10, as Rogers notes); Leland quotes the Massachusetts constitutional provision that states "it is the right and duty of all men publicly, and at stated seasons, to worship the Supreme Being" and comments that it "would read much better in a catechism than in a state constitution." Yankee Spy, supra, at 220 .

74. 1 BRANT, supra note 50, at $410 \mathrm{n} .11$ ("In 1781, a Baptist preacher named Leland applied to the elder Madison [James Madison, Sr.] for permission to preach in the Pine Stake church at Mountain Run, then without a rector. ...").

75. See RalPh Ketcham, James Madison: A BIOGRAPHy 251 (1971) ("[A]s a leader of the great Baptist revival in Virginia that had accompanied the revolution, Leland knew very well of Madison's early and continuing support of religious liberty."). Ralph Rutland asserts that "[s]urely Madison discussed the matter with his neighbors, including the obstreperous Elder John Leland, who loathed all forms of church-state alliances." Robert A. Rutland, James Madison's Dream: A Secular Republic, in JAMES MADISON ON RELIGIOUS LIBERTY 199, 202 (Robert S. Alley ed., 1985).

76. 2 IRving Brant, James Madison: The Nationalist (1780-1787) 343-44 (1948); see MCCONNELL, supra note 19, at 48; Marvin K. Singleton, Colonial Virginia as First Amendment Matrix: Henry, Madison, and Assessment Establishment, in JAMES MADisON ON Religious LIBERTY 157, 161-68 (Robert S. Alley ed., 1985); Forrest Church, Introduction to Memorial and Remonstrance, in THE SEPARATION OF CHURCH aNd State: Writings on a Fundamental FreEdom by AmERICA's Founders 56, 58 (Forrest Church ed., 2004) ("With Jefferson in Paris as American ambassador, James Madison took charge swiftly, opportunistically marshaling the opposition."). In the summer of 1784, Jefferson sailed for Europe, to act as an American diplomat. He did not return until November, 1789. See, e.g., The Early Republic: 1784-1789, part of The Thomas Jefferson Timeline on the Library of Congress's website, at http://memory.loc.gov/ammem/collections/jefferson_papers/mtjtime3a.html (last visited Aug. 12, 2008). Jefferson thus was not present during the Virginia religious assessment 
was vehemently opposed by Virginia's Baptists. ${ }^{77}$ (Of course Madison also wrote the influential 1785 Memorial and Remonstrance Against Religious Assessments, ${ }^{78}$ but he did so anonymously and did not publicly state that he was the author until $1826 .{ }^{79}$ )

controversy-or for the drafting and ratification of the Constitution, or for Congressional consideration of a Bill of Rights (which concluded with the Senate's concurrence in House amendments on Sept. 25, 1789, see Journal of the Senate 88 (Sept. 25, 1789) \& Appendix 96-97, 1st Cong. (1st Sess., 1789) (recording Senate concurrence and containing, in Appendix, text of proposed amendments), available at http://memory.loc.gov/ammem/amlaw/lwsjlink.html (last visited Aug. 27, 2008)).

77. See SEMPLe, supra note 38 , at 95-95; William TAYlor ThOM, THE Struggle FOR Religious Freedom IN VIRGINIA: The BAPTISTS 75-78 (Johns Hopkins Press 1900), available at http://books.google.com/books?id=4Nc0AAAAIAAJ; Singleton, supra note 76 , at 163.

78. JAMES MAdison, MEMORIAL AND REMONSTRANCE Against REligious ASSESSMENTS (1785), reprinted in MCCONNELL, supra note 19, at 49-53, available at http://press-pubs.uchicago.edu/founders/documents/amendI_religions $43 . \mathrm{html}$.

79. LABUNSKI, supra note 57, at 164-65 ("Madison had good reason for hiding his authorship of the Memorial, which he did not explicitly acknowledge until 1826, when he was seventy-five. Like most authors when seeking anonymity, he wanted the arguments in the document, and not the political affiliations of the writer, to be the focus of attention. Madison also did not want to alienate important people-whose support he would need on other matters-who energetically promoted the assessments bill...."); see also Donald L. Drakeman, Religion and the Republic: James Madison and the First Amendment, in JAMES MADISON ON RELIGIOUS LIBERTY 231, 236 (Robert S. Alley ed., 1985) ("The Memorial and Remonstrance was circulated as a petition, and did not bear Madison's name as author."); NoONAN, supra note 19, at 178 ("Not anxious to alienate allies on other subjects who were in favor of Henry's bill, Madison had the petition circulated anonymously...."); Dreisbach, supra note 51, at 152 ("Interestingly, Madison was so successful in shielding his authorship of the 'Remonstrance' and Mason was so zealous in his support of it that there was contemporaneous speculation attributing the document to Mason's pen." (footnote omitted)). Madison took the lead in the Virginia legislature in opposing the assessment bill. (For example, in November, 1784-months before Madison wrote the Memorial and Remonstrance-"Madison and Henry delivered set speeches against each other's position" on the assessment bill. Singleton, supra note 76, at 163.) It is not clear why Madison would do that publicly but not put his name on the Memorial and Remonstrance. For interesting speculation on Madison's motives in "seeking a cloud of anonymity," and why he finally claimed authorship, see Rutland, supra note 75 , at $202-04$.

Note also that Madison's Memorial and Remonstrance may not have been as important to the defeat of the assessment bill as is sometimes thought, since there were about eighty petitions against Henry's bill. See LABUNSKI, supra note 57, at 164 . A Petition of the Inhabitants of Cumberland County "obtained 4,899 subscribers, over three times the number of those who signed Madison's petition," and "[i]n all, 10,929 persons indicated opposition to Henry's bill... The Evangelicals, especially the Baptists, provided the decisive numbers." NoONAN, supra note 19, at 178, 180. Rutland suggests that, given its content, the Cumberland County petition probably was written by a Baptist. Rutland, supra note 75 , at 204 . Madison wrote to Jefferson that " $[t]$ he table was loaded with petitions \& remonstrances from all parts against the interposition of the Legislature in matters of Religion." NOONAN, supra note 19, at 180 . For a list of petitions, see THOM, supra note 77 , at 77-78. 
In any event, Leland must have been aware of Madison's role. Leland was intensely interested in religious liberty and also believed that, as a good citizen, he should stay informed of public matters. ${ }^{80}$ Even if somehow Leland were otherwise oblivious to what must have been known about his neighbor by almost everyone in Virginia, he would have found out about it as a result of his service for the Baptist General Committee.

The Baptists in Virginia had formed the Baptist General Committee in 1783 to continue the religious freedom work of the Baptist General Association. $^{81}$ The Committee was to "consider all the political grievances of the whole Baptist Society in Virginia" and to serve the exclusive role of presenting any Baptist "petition, memorial, or remonstrance" on behalf of any Baptist Association to the state legislature. $^{82}$ As Butterfield points out, a lack of records makes it "difficult to say just what part John Leland had" in the struggle over the assessment bill, though "there is little doubt that he normally attended and participated in the deliberations of the General Association [before 1783] and its successor (after 1783), the General Committee." 83

80. See Letter from John Leland to James Madison (ca. Feb. 15, 1789), in 10 PAPERS OF JAMES MADISON, supra note 12, at 442-43 (asking Congressman-elect Madison to provide various kinds of information about the new federal government, insisting that there is "No Danger of the Destruction of Liberty where the Community is well informed," and stating, "One Thing I shall expect; that if religious Liberty is anywise threatened, that I shall receive the earliest Intelligence"); Rogers, supra note 12, at 289 n.48 (noting that Leland "believed Christians should be good citizens of the state").

81. See supra note 38 .

82. See id.

83. Butterfield, supra note 2, at 177 . Your author has not yet located any primary source supporting a claim that Leland was involved in the assessment controversy, though it seems likely he was in the thick of it. In an unfootnoted lecture, the eminent church historian Edwin Gaustad stated that Leland "helped gather signatures for Madison's vital Memorial and Remonstrance, even as he lobbied for enough votes to help pass Jefferson's Bill for Establishing Religious Freedom. EDWIN S. GAUSTAD, Baptist Trumpets of Religious Liberty in Early America, in THE BAPTIST TRADITION OF Religious Liberty in America: Two LeCtures by Edwin SCOTT Gaustad 3, 12 (undated pamphlet printed by J.M. Dawson Institute of Church-State Studies, Baylor University) (containing lectures given by Gaustad on March 30-31, 1995 at the J.M. Dawson Institute). Ralph Ketcham confidently states that Madison and Leland "worked together in Richmond in 1784 and 1785 to defeat" the assessment bill, though the authority for that statement is not clear. KETCHAM, supra note 75, at 251; see Ralph L. Ketcham, James Madison and Religion: A New Hypothesis, in JAMES MADISON ON Religious LiBERTY 175, 185 (Robert S. Alley ed., 1985) (reprinted from $38 \mathrm{~J}$. PRESBYTERIAN HIST. SOC'Y No. 2 (June 1960)) ("During the fight over religious assessments in 1784 and 1785 , Leland, violently opposed to the assessment, was a lobbyist in Richmond, where he no doubt worked with Madison....") (so stating without citing any authority). Robert Alley similarly states (without citing relevant authority) that Leland was "[a]ctively involved" in the opposition to the religious assessment and was one of Madison's "strongest supporters" in the matter. Robert S. Alley, Jefferson and the Danbury Baptists: The Interaction between Baptists and the Nation's Founders, in 
The picture becomes clearer with the Baptist General Committee's August 5, 1786, meeting. Reuben Ford, who had been representing Baptist interests before the Virginia legislature for at least three years, reported the defeat of the assessment bill and the passage of Jefferson's Bill for Establishing Religious Freedom. ${ }^{84}$ Leland attended the meeting

Freedom of Conscience: A Baptist/Humanist Dialogue 41, 42 (Paul D. Simmons ed., 2000). The editor of that volume states in his contribution to it that Patrick Henry's assessment bill "was opposed by backcountry Baptists led by John Leland." Paul D. Simmons, James Madison, the Baptists, and Religious Liberty, in FrEEDOM of Conscience: A Baptist/Humanist Dialogue at 50, 54. Michael McConnell writes that Leland was "the leader of the Virginia Baptists during the assessment controversy," though without citing authority for that particular proposition. Michael W. McConnell, Freedom from Persecution or Protection of the Rights of Conscience?: A Critique of Justice Scalia's Historical Arguments in City of Boerne v. Flores, 39 WM. \& MARY L. REV. 819 (1998); McConnell, supra note 37, at 1448. Similarly, Nathan Hatch states (with only general references to various accounts of Leland's activities) that "Leland had been influential in petitioning the legislature on behalf of Jefferson's bill for religious freedom." Hatch, The Democratization of Christianity and the Character of American Politics, supra note 12, at 109; HATCH, THE DEMOCRATIZATION OF AMERICAN CHRISTIANITY, supra note 12, at 95; see also ARLIN M. ADAMS \& CHARLES J. EMMERICH, A Nation Dedicated to Religious Liberty: The Constitutional Heritage of the RELIGION CLAUSES 12 (1990) (stating without citation of relevant authority that "[t]he Baptist minister John Leland led his denomination in support of Jefferson's bill and worked for complete disestablishment in Virginia"); Arlin M. Adams \& Charles J. Emmerich, A Heritage of Religious Liberty, 137 U. PA. L. REv. 1559, 1575 (1989) (same). Leonard Levy even suggests that Leland influenced Madison's Memorial and Remonstrance. LeONARD W. LeVy, The Establishment Clause 229 (1994) ("Madison's 'Memorial and Remonstrance' bore the influence of his Orange County neighbor, the great Baptist preacher John Leland...."). "According to C.A. Browne, 'Leland's influence was a great factor in winning the rank and file of Virginia's population to the support of Jefferson's bill for the complete separation of church and state." Dreisbach \& Whaley, supra note 21 , at 640 (footnote omitted) (citing C.A. Browne, Elder John Leland and the Mammoth Cheshire Cheese, 18 AGRIC. HIST. 145 (1944)). According to Butterfield, Browne's article is "[ $t]$ he fullest account of the making of the cheese" and "is a well-documented account [that] draws alike on historical and traditional materials." Butterfield, supra note 2, at $221 \mathrm{n} .147$.

84. In 1780 Ford had been chosen by the General Association to serve on a three person committee to coordinate religious freedom activities with another Baptist group's committee. SEMPLE, supra note 38, at 90 . In 1783 he was chosen to represent the General Association's concerns before the Virginia legislature. Id. at 93. In 1784, at its first meeting, the Baptist General Committee chose Ford to be its clerk and to present a memorial to the Virginia legislature (the Virginia General Assembly). Id. at 95 . At its 1785 meeting, alarmed by the introduction in the Virginia General Assembly of Patrick Henry's religious assessment bill, the Committee passed a resolution opposing it, urged Baptists in the various counties to send petitions against it to the General Assembly, "agree[d] unanimously that it w[ould] be expedient to appoint a delegate to wait on the General Assembly with a remonstrance and petition against such assessment," and appointed Ford to be the delegate. Id. at 96-97. Ford reported success at the Committee's 1786 meeting; he "reported that he waited on the House of Assembly as appointed; that the law for assessment did not pass, but on the contrary, an act passed explaining the nature of religious liberty." Id. at 97. The act that Ford reported as passing was Jefferson's Bill for Establishing Religious Freedom. See MCCONNELL, supra note 19 , at $54-55$. 
and was appointed to join with Ford in representing Baptist interests at the next session of the Virginia legislature. ${ }^{85}$

Given that Madison led the effort in the legislature to defeat the assessment bill and to pass Jefferson's Bill, Madison's role in favor of religious liberty would have been blindingly obvious to Ford and very likely a topic of discussion at the August 5, 1786, meeting. Butterfield reports that the Baptists were Madison's only allies at first in the assessment controversy, ${ }^{86}$ which likely meant that Madison and Ford coordinated their efforts. ${ }^{87}$ In addition, the notion that Leland would have worked with Ford as, in essence, a lobbyist for the Baptists, without talking with Ford at length about the views of Madison and other legislative leaders is not credible. Madison was still a member of the Virginia legislature and had not yet left Virginia to attend the Confederation Congress in New York; thus, Madison's views would have been very important to Ford and Leland as they worked together. ${ }^{88}$

The Committee had asked them to seek "repeal of the act incorporating the Episcopal Church," which the Episcopal Church had obtained in an attempt to protect "the extensive property it held under the old establishment," ${ }^{, 99}$ (property which had been obtained to some degree from the colonial governments or by taxation of all the people and which therefore, the Baptists thought, should not be the property of one

85. Events, supra note 1, at 25; SEMPLE, supra note 38, at 98 . Leland was appointed even though he had only been ordained as a minister by a church and not yet by a "presbytery" (a group) of ministers. In June 1787 he was ordained by a presbytery of ministers, likely increasing Leland's influence among Virginia Baptists. See supra note 54. In addition, people were responding to his preaching in unusually large numbers "from October, 1787, until March, 1789, during which time [he] baptized about 400." Events, supra note 1, at 27.

86. Butterfield, supra note 2, at 176.

87. Cf. Letter from George Nicholas to James Madison (Jan. 2, 1789), in 10 PAPERS OF JAMES MADISON, supra note 12, at 406, 407, 409 n.6 ("[Y]ou should write to Ford the preacher... whom you know.") (stating in editors' note 6 that "Ford the preacher" was Reuben Ford).

88. See 3 Irving Brant, James Madison: Father of the Constitution (17871800 ) 10 (1950) (giving chronology that shows Madison not leaving for Congress in New York until February, 1787).

89. Butterfield, supra note 2, at 177 . "At issue was the property held by what had been the established Church of England: the churches and chapels, the communion plate and liturgical books, and the glebe lands, homes, barns, and slaves set aside for ministers' use. Colonial legislation had provided for such property, and over the years it accrued from public sources and private donations.... East of the Blue Ridge, these holdings were often extensive and sometimes quite valuable." Thomas E. Buckley, Evangelicals Triumphant: The Baptists' Assault on the Virginia Glebes, 1786-1801, 45 WM. \& MARY Q. 33, 34 (1988) (footnote omitted), available at http://www.jstor.org/stable/1922213. For information about a 19th Century silversmith who made very valuable "communion plate," see Jennifer M. Swope, Francis W. Cooper: Silversmith, Magazine AnTiQues (Feb. 1999), available at http://findarticles.com/p/articles/mi_ml026/is_2_155/ai_ 54010687?tag=untagged (last visited Aug. 12, 2008). 
denomination). As a result, Ford and Leland presented to the Virginia legislature a petition which, according to Butterfield, "has the ring of Leland's style and which is one of the most forceful expressions of principles that the long controversy in Virginia produced.",90

In 1787, Ford and Leland reported to the Committee that the legislature had repealed the provisions for incorporation and governance of the Episcopal Church, but not the provisions that allowed the Episcopal Church to keep the glebe lands and other property. ${ }^{91}$ Madison thought the property issue raised real difficulties, and apparently he voted against taking the property from the Episcopal Church. ${ }^{92}$ The Baptists had achieved only part of what they sought. ${ }^{93}$ Historian Thomas Buckley describes it as "a significant step, but not sufficient to satisfy the Baptists;" Buckley suggests that the Baptists received "the smaller portion of the loaf."

Thus, on the eve of the Constitutional Convention, Leland and the Virginia Baptists would have had reason to be grateful to Madison for his leadership-leadership with respect to the 1776 Virginia Declaration of Rights, the defeat of the assessment bill, and the passage of Jefferson's

90. Butterfield, supra note 2, at 177-78.

91. SEMPLE, supra note 38 , at 99 . "Realizing that any decision they made would offend a sizable element of Virginia's population, the politicians compromised. A brief bill authorized all religious societies to appoint trustees to hold and manage their property and repealed the incorporation act as well as any other acts that inhibited the Episcopal church from regulating its own affairs." Buckley, supra note 89 , at 40 . Buckley's article provides an in-depth discussion of the property issue.

92. Buckley, supra note 89 , at 40 . Buckley quotes from a letter from Madison to Jefferson that says the glebes bill "involved the Legislature in some embarrassment," and a letter from Benjamin Johnson to Madison (discussed at length below, text accompanying notes 320-28, describing George Eve's defense of Madison in Madison's congressional race against James Monroe) as the basis for his view that Madison probably voted against seizing the glebe lands. See Letter from James Madison to Thomas Jefferson (Feb. 15, 1787), in 9 THE PAPERS OF JAMES MADISON 267, 268 (Robert A. Rutland \& William M.E. Rachal eds., 1975); Letter from Benjamin Johnson to James Madison (Jan. 19, 1789), in 11 PAPERS OF JAMES MADISON, supra note 12, at 424 . A Monroe biographer relies on the same letter from Benjamin Johnson for the following description of the meeting at which George Eve defended Madison: "When the Baptists were reminded that Madison had at one time voted against the sale of the glebe lands of the Episcopal Church, Madison's friends were ready with the reply that Monroe had himself voted the same way on another occasion." HARRY AMMON, JAMES MONROE: THE QUEST FOR NATIONAL IDENTITY 77, 592 n.69 (1971).

93. Eventually they succeeded. In 1799 the laws providing for the Episcopal Church to retain the glebe lands were repealed, and in 1802 the Virginia legislature enacted legislation calling for the glebe lands to be sold. Buckley, supra note 89 , at 36 . The 1802 legislation allowed the Episcopal Church to retain its "churches, church yards, books, and communion plate," with glebe lands to be "sold by the overseers of the poor in any vacant parish or whenever an incumbent [Episcopal] minister resigned or died." Id. at 54 .

94. Id. at $40-41$. 
Bill for Establishing Religious Freedom-but also reason to question whether he was fully supportive of their concerns. ${ }^{95}$

\section{MADISON'S ELECTION TO THE VIRGINIA RATIFYING CONVENTION}

The Philadelphia Convention concluded on September 17, 1787, with the signing of the Constitution. ${ }^{96}$ Ominously, two important Virginians-George Mason and Governor Edmund Randolph, "the official head of the Virginia delegation"97_refused to sign. ${ }^{98}$ Randolph refused to sign despite a last-minute concession made to try to gain his support, ${ }^{99}$ but not because he had made up his mind to oppose ratification; rather, he was reserving decision. ${ }^{100} \mathrm{~A}$ few days later Madison left for New York to serve in the Confederation Congress, which would consider how to transmit the proposed Constitution to the states. ${ }^{101}$ The federalist (pro-Constitution) members of the Congress blocked an attempt to change the Constitution (including by addition of a bill of rights) prior to its submission to the people of the states, and, in order to obtain unanimity among the Congressmen, agreed that the Constitution would be sent to the state legislatures without endorsement by or advice from the Congress. ${ }^{102}$ Thus, on September 28,1787 , the Congress unanimously resolved that the report of the Convention

with the resolutions and letter accompanying the same be transmitted to the several legislatures in Order to be submitted to a convention of Delegates chosen in each state by the people thereof in conformity to the resolves of the Convention made and provided in that case. ${ }^{103}$

95. As noted above and discussed below, Madison's vote against the seizure of the glebe lands was used against him by Baptist critics in the campaign for the congressional election of February, 1789. See supra note 92 and infra text accompanying note 327.

96. 3 BRANT, supra note 88 , at $153-54$.

97. KeTCHAM, supra note 75 , at 192.

98. Id. at $228 ; 3$ BRANT, supra note 88 , at 153 ; LABUNSKI, supra note 57 , at 12 .

99. 3 BRANT, supra note 88 , at 152 (reducing population of house districts from 40,000 to 30,000 , a proposal supported by George Washington in his only speech at the Philadelphia Convention).

100. Id.; KETCHAM, supra note 75, at 228.

101. KETCHAM, supra note 75, at 231.

102. Id. at 231-32; 3 BRANT, supra note 88 , at 161-62; LABUNSKI, supra note 57 , at 16-18.

103. 33 Journal of the Continental Congress 549 (Sept. 28, 1787) (U.S. Gov't Printing Office 1936), available at http://memory.loc.gov/ammem/amlaw/lwjclink.html (by selecting volume 33, then selecting "Navigator," and then selecting "Friday, September 28, 1787') (last visited Aug. 15, 2008). The referenced report, resolutions, and letter are George Washington's letter of transmittal, the body of the Constitution as transmitted with names of signers, and the Convention resolutions recommending steps for implementation. See Supplement to the Independent Journal (Sept. 22, 1787) 1-4 (New York, J. M'Lean \& Co. 1787), available at http://memory.loc.gov/ammem/collections/ 
Madison stayed in New York until March 4, 1788 (except for a brief visit to Philadelphia), working on congressional matters (including difficult funding issues), writing his parts of what became the Federalist Papers, ${ }^{104}$ corresponding with Governor Randolph to persuade him to support the Constitution, and coordinating the Confederation-wide ratification effort. ${ }^{105}$

Madison knew early on that George Mason and Richard Henry Lee (in Brant's words "Virginia's No. 2 orator" 106 ) were firmly opposed to the Constitution. ${ }^{107}$ On October 24, 1787, Madison wrote Jefferson to say that he thought Patrick Henry ("Orator No. 1"108) would oppose it, too, but Madison was not sure: "The part which Mr. Henry will take is unknown here. Much will depend on it."109 In fact, Henry had already started working in Richmond against the Constitution, as Madison learned when he received Archibald Stuart's letter of October 21, $1787 .^{110}$

The Virginia General Assembly had met on Monday, October 15, $1787,{ }^{111}$ with the Virginia Senate in session by Wednesday, October 17, 1787. ${ }^{112}$ Patrick Henry had declared his opposition to the proposed Constitution, ${ }^{113}$ though he thought that consideration of it was beyond the powers of the Virginia legislature, and thus "that it must go before a Convention." 114 Both houses approved resolutions (the Assembly unanimously on the 25th and the Senate on the 31st) providing for the proposed Constitution to be submitted "to a Convention of the people for their full and free investigation, discussion, and decision," with the

continental/bdsdcoll2.html (by using search term "supplement September 22") (last visited Aug. 15, 2008); LABUNSKI, supra note 57, at 16.

104. 3 BRANT, supra note 88 , at $162-85$.

105. See KETCHAM, supra note 75, at 232.

106. 3 BRANT, supra note 88 , at 162.

107. Id at 141-42, 161-63; Finkelman, supra note 12, at 315-16.

108. 3 BRANT, supra note 88 , at 162.

109. Letter from James Madison to Thomas Jefferson (Oct. 24, 1787), in 10 PAPERS OF JAMES MADISON, supra note 12, at 217; see also Letter from James Madison to William Short (Oct. 24, 1787), in 10 PAPERS OF JAMES MADISON, supra note 12, at 221 ("Virga. I fear will be divided and extremely agitated ... [but] [t] he general impression as far as it has come to my knowledge, is rather on the favorable side.").

110. Letter from Archibald Stuart to James Madison (Oct. 21, 1787), in 10 PAPERS OF JAMES MADISON, supra note 12, at 202.

111. Id.

112. Letter from John Dawson to James Madison (Oct. 19, 1787), in 10 PAPERS OF JAMES MADISON, supra note 12, at 198.

113. Letter from Archibald Stuart to James Madison, supra note 110 ("Mr. Henry has upon all Occasions however foreign his subject attempted to give the Constitution a side blow.").

114. Letter from George Washington to James Madison (Oct. 22, 1787), in 10 PAPERS OF JAMES MADISON, supra note 12, at 204. 
convention to meet in Richmond. ${ }^{115}$ The Senate's suggested date for the convention-June 2, 1788 (the first Monday in June)-was accepted. ${ }^{116}$

The election for Orange County's two delegates to the ratifying convention was set for March 24, 1788. ${ }^{117}$ Many friends urged Madison to stand for election, ${ }^{18}$ including one who used a "tone that few correspondents used in letters to Madison"119:

It is generally considered necessary that you should be of the convention, not only that the Constitution may be adopted but with as much unanimity as possible.

For God's sake do not disappoint the Anxious expectations of yr friends \& let me add of yr Country. ${ }^{120}$

Madison initially declined to serve but finally changed his mind: ${ }^{121}$

I am to observe that it was not my wish to have followed the Act of the General [Philadelphia] Convention into the Convention of the State; supposing that it would be as well that the final decision thereon should proceed from men who had no hand in preparing and proposing it. As I find however that in all the States the members of the Genl. Convention are becoming members of the State Conventions, as I have been applied to on the subject by sundry very respectable friends, as I have reason to believe that many objections in Virginia proceed from a misconception of the plan, or of the causes which produced the objectionable parts of it; and as my attendance at Philadelphia, may enable me to contribute some explanations and informations which may be of use, I shall not decline the representation of the County if I should be honored with its appointment. ${ }^{122}$

That did not mean that Madison was prepared to campaign publicly-which seemed to him to be inappropriate-or even that he

115. 10 PAPERS OF JAMES MADISON, supra note 12, at $231 \mathrm{n} .1$ (editorial note quoting resolutions as printed in 4 DOCUMENTARY HISTORY OF THE CONSTITUTION 366-68 (1905) (available at http://books.google.com/books?id=9tJWAAAAMAAJ)); LABUNSKI, supra note 57 , at $49-56$.

116. LABUNSKI, supra note 57 , at 55-56.

117. Id. at 30 .

118. 3 BRANT, supra note 88 , at 170 ; KETCHAM, supra note 75 , at 249-50; LABUNSKI, supra note 57 , at $43-44$.

119. LABUNSKI, supra note 57, at 44.

120. Letter from Archibald Stuart to James Madison (Nov. 2, 1787), in 10 PAPERS OF JAMES MADISON, supra note 12, at 234. Stuart was a Virginia legislator. See LABUNKSI, supra note 57 , at 58 .

121. LABUNSKI, supra note 57, at 22-23, 30; 3 BRANT, supra note 88, at 170.

122. Letter from James Madison to Ambrose Madison (Nov. 8, 1787), in 10 PAPERS OF JAMES MADISON, supra note 12, at 244. 
would return to Orange County for the election ${ }^{123}$ in which he and James Gordon, Jr. would be the federalist candidates competing against two antifederalist candidates, Thomas Barbour and Charles Porter. ${ }^{124}$ Friends and relatives now pleaded with him to return to Virginia in time to campaign in Orange County, ${ }^{125}$ or at least to be present for the election. ${ }^{126}$ His father wrote Madison on January 30,1788 , saying that:

The Baptists are now generally opposed to it [the Constitution], as it is said. Col. Barbour has been down on Pamunky ${ }^{[127]}$ amongst them, $\&$ on his return, I hear, publickly declared himself a candidate [for the ratification convention], I suppose, on the encouragement he met with from the Antifederalists.... I think you had better come in as early in March as you can: many of your friends wish it; there are some who suspends [sic] their opinion till they see you, \& wish for an explanation, others wish you not to come, \& will endeavor to shut you out of the Convention, the better to carry their point. ${ }^{128}$

This letter did not go out until at least the next day; we know that because William Moore, Madison's half-uncle, used the reverse side of the same sheet of paper to write Madison a letter dated January 31 . Moore wrote, "I must therefore intreat and conjure you nay commd. you, if it was in my Power, to be here in Feberuary [sic] or the first of March... [P]ray don't disappoint the wishes of your friends and many others. ..." ${ }^{29}$ Then, on February 18, John Dawson wrote to Madison, saying, "I must therefore join your other friends and intreat your attendance at the election." 130

Three other letters to Madison deserve special attention, focusing, as Madison's father had, on the large Baptist electorate, including specifically (in the case of two of the letters) John Leland, "the leader of

123. LABUNSKI, supra note 57, at 31-34.

124. See Butterfield, supra note 2, at 184-85; KETCHAM, supra note 75, at 266.

125. Butterfield, supra note 2, at 184; Letter from Lawrence Taliaferro to James Madison (Dec. 16, 1787), in 10 PAPERS OF JAMES MADISON, supra note 12, at 329; Letter from Henry Lee to James Madison (ca. Dec. 20, 1787), in 10 PAPERS OF JAMES MADISON, supra note 12, at 340; Letter from Andrew Shepherd to James Madison (Dec. 22, 1787), in 10 PAPERS OF JAMES MADISON, supra note 12, at 344.

126. Letter from Edmund Randolph to James Madison (Jan. 3, 1788), in 10 PAPERS OF JAMES MADISON, supra note 12, at 350; Letter from John Dawson to James Madison (Feb. 18, 1788), in 10 PAPERS OF JAMES MADISON, supra note 12, at 518.

127. See 10 PAPERS OF JAMES MADISON, supra note 12, at $516 \mathrm{n} .2$ (stating in editorial note that "Aaron Bledsoe... was a Baptist minister who preached at "North Fork of Pamunkey,' about eight miles southeast of Orange").

128. Letter from James Madison, Sr., to James Madison, Jr. (Jan. 30, 1788), in 10 PAPERS OF JAMES MADISON, supra note 12, at 446.

129. Letter from William Moore to James Madison (Jan. 31, 1788), in 10 PAPERS OF JAMES MADISON, supra note 12, at 454-55 (including editors' note: "Written on the verso of James Madison, Sr., to JM, 30 Jan. 1788"); Butterfield, supra note 2, at 184.

130. Letter from John Dawson to James Madison, supra note 126, at 518. 
the Virginia Baptists."131 The first was from James Gordon, Jr., the other Orange County federalist candidate for convention delegate, who wrote on February 17, 1788, that he would:

take the liberty as yr. friend to solicit your attendance at the Orange court [election].... The sentiments of the people of Orange are much divided the $[s i c]$ best men in my judgement are for the constitution but several of those who have much weight with the people are opposed, Parson Bledsoe \& Leeland [sic] with Colo. Burnley. Upon the whole sir I think it is incumbent on you with out delay, to repair to this state; as the loss of the constitution in this state may involve consequences the most alarming to every citizen of America. ${ }^{132}$

Receipt of this letter, perhaps together with Dawson's (indicating that the influential anti-federalist George Mason likely would be a delegate), ${ }^{133}$ seems to have finally convinced Madison to return home, ${ }^{134}$ though he apparently did not hurry.

On March 4, 1788, Madison left New York for Philadelphia, ${ }^{135}$ where he "lingered a week." 136 Madison arrived in Mount Vernon on March 18, spent a day with Washington, and left for Fredericksburg (taking the stagecoach from Colchester, a journey of about thirty-four miles, at least on modern roads) the morning of March 20, 1788, ${ }^{137}$ presumably arriving in Fredericksburg that evening.

The second letter of particular interest was from Edmund Randolph, dated February 29, 1788. No information has been found showing when or where Madison received it, though it might be thought that some trouble would be taken to deliver a letter from the Governor. In any event, Randolph wrote that " $[\mathrm{t}]$ he baptist interest and the Counties on the

131. 10 PAPERS OF JAMES MADISON, supra note 12, at $516 \mathrm{n} .2$ (editorial note); see also supra notes 75,83 .

132. Letter from James Gordon, Jr. to James Madison (Feb. 17, 1788), in 10 PAPERS OF JAMES MADISON, supra note 12, at 515-16.

133. See LABUNSKI, supra note 57, at 23-28, 46.

134. Madison wrote Washington on February 20, 1788 saying that he would attend the election in Orange County "if I am informed that my presence ... is indispensable." Letter from James Madison to George Washington (Feb. 20, 1788), in 10 PAPERS OF JAMES MADISON, supra note 12, at 526-27 (emphasis added). The same day (perhaps after receiving or digesting Gordon's and Dawson's letters), Madison wrote to Jefferson that "[b]y letters just received from Virginia I find that I shall be under the necessity of setting out in 8 or 10 days for Virginia." Letter from James Madison to Thomas Jefferson (Feb. 20, 1788), in 10 PAPERS OF JAMES MADISON, supra note 12, at 526 .

135. KETCHAM, supra note 75, at 250; 10 PAPERS OF JAMES MADISON, supra note 12 , at $542 \mathrm{n} .4$ (giving departure date as March $3 \mathrm{rd}$ or 4 th).

136. 3 BRANT, supra note 88, at 187; see also KETCHAM, supra note 75, at 250.

137. 3 BRANT, supra note 88 , at 187 ; see also KETCHAM, supra note 75 , at $250-51$; 10 PAPERS OF JAMES MADISON, supra note 12, at 542 n.4. Google Maps gives the distance by road between Colchester, Virginia, and Fredericksburg, Virginia, as 34.2 miles. 
So. Side of Jas. River from Isle of Wight, upwards, are highly incensed by $\mathrm{H}-\mathrm{y}$ 's opinions and public speeches, whenever occasion has presented."138 That the Baptists generally—not just Baptists south of the James River, if the rule of the last antecedent is sensibly applied herewere being influenced by Patrick Henry's antifederalist rhetoric would have alarmed Madison, since Madison and the Baptists had joined forces against Henry in the religious assessment controversy. ${ }^{139}$

The third letter, Joseph Spencer's letter of February $28,{ }^{140}$ which Madison received when he arrived in Fredericksburg, ${ }^{141}$ had an

138. Letter from Edmund Randolph to James Madison (Feb. 29, 1788), in 10 PAPERS OF JAMES MADISON, supra note 12 , at 542.

139. See supra text accompanying notes $75-86$.

140. Letter from Joseph Spencer to James Madison (Feb. 28, 1788), in 10 PAPERS OF JAMES MADISON, supra note 12 , at 540.

141. 3 BRANT, supra note 88, at 188; Butterfield, supra note 2, at 185; see also Stuart Leibiger, James Madison and Amendments to the Constitution, 1787-1789: "Parchment Barriers," 59 J. S. Hist. 441, 451 (1993). Spencer sent the letter to Madison in "care of a Mr. F Murey [Maury] in Fredericksburg." 10 PAPERS OF JAMES MADISON, supra note 12, at 541 (editors' comment quoting language from envelope or other source and accepting Feb. 28 date written at beginning of letter rather than Feb. 26 date written at end of letter) (addition of "[Maury]" by editors). Robert Alley - who argues that Madison likely did not meet with Leland before the March 24 election-admits that Spencer's letter probably was delivered to Madison while he was in Fredericksburg, but points out that "there is no written evidence that the letter was actually delivered on [March] 21st. All that is known for certain is that Madison eventually received the letter and recorded it as being dated February 26, 1788." Robert S. Alley, Public Education and the Public Good, 4 WM. \& MARY BILL RTS. J. 277, 294 (1995). There is no reason to think it was not delivered to Madison when he arrived in Fredericksburg (or at least the next morning), which seemingly would have been the ordinary course of affairs. Madison attested to Maury's trustworthiness and diligence, in response to a request from George Washington for a secure means of communication with Madison: "Mr. F. Maury pays particular attention to all letters which arrive there [Fredericksburg] for me, and forwards them to Orange by opportunities which are frequent \& safe. I apprehend there will be no impropriety in committing a confidential letter to that channel." Letter from James Madison to George Washington (Jan. 14, 1789), in 11 PAPERS OF JAMES MADISON, supra note 12, at 417. Maury would have known that Madison was not in Orange County at Montpelier but would have to pass through Fredericksburg en route home; thus Maury almost certainly held the letter in Fredericksburg pending Madison's arrival instead of forwarding it to Montpelier. It appears that Spencer sent the letter to Madison in Fredericksburg care of Maury, instead of sending it to Madison at Montpelier, because Spencer wanted Madison to receive it en route, instead of at Montpelier. "F Maury" may have been Fontaine Maury, who later became mayor of Fredericksburg. See TED KAMIENIAK, FREDERICKSBURG, VIRGINIA: ECLECTIC HISTORIES FOR THE CURIOUS READER 135, 138 (2008) (noting actions taken by Fontaine Maury as mayor of Fredericksburg in 1796), limited preview available at http://books.google.com/books? id =cMzBw_8z9_gC; The Fontaine-Maury Society, The Maury Family - A Brief History, http://www.stithvalley.com/fontaine/mauryhist.html (last visited Feb. 2, 2009) (noting that Fontaine Maury was "mayor of Fredericksburg, Virginia, during the 1790s and early 1800s") (also noting prominent members of the Maury family); JAMES MADISON, CALENDAR OF THE CORRESPONDENCE OF JAMES MADISON 507 (1970 reprint by Ayer Publishing of 1894 State Department edition) (listing correspondence with Fontaine 
enclosure, a copy of a letter from John Leland to Thomas Barbour. ${ }^{142}$ Spencer's letter and the enclosed copy of Leland's letter are critical documents for our purposes. As Butterfield explains, Madison:

did not think it necessary to make a canvass [to campaign] himself and allowed no time to do so, lingering in Philadelphia a week and stopping overnight to discuss the prospects of ratification with the master of Mount Vernon. But at Fredericksburg he was greeted with a letter that caused him to do some last-minute and very important canvassing. ${ }^{143}$

Spencer wrote that Barbour (one of the antifederalist candidates opposing Madison) had been prejudicing the "we[a]ker clas[s]" of people against the Constitution and winning supporters ("Friends") through misrepresentations. ${ }^{144}$ Among those "Friends" who were being prejudiced against the Constitution were:

in a General way the Baptus's, the Prechers of that Society are much alarm'd fearing Relegious liberty is not Sufficiently secur'd thay pretend to other objections but that I think is the principle objection, could that be Removed by sum one Caperble of the Task I think thay

Maury beginning in 1789), limited preview available at http://books.google.com/books?id=qzbbk55kIBAC. It appears that Fontaine Maury's uncle was Reverend James Maury, plaintiff in the "Parson's Cause" case that helped to make Patrick Henry famous, and also proprietor of a school attended by Thomas Jefferson, James Madison, and James Montoe. See Merrill Jensen, The Founding of A NATION: A History of THE AMERICAN Revolution (1763-1776) 101-03 (2004 Hackett Publishing reprint of 1968 Oxford University Press edition), limited preview available at http://books.google.com/books?id=peTnoR_-PdAC; (describing Patrick Henry's defense of Rev. James Maury's "Parson's Cause" suit for his clergyman's salary); HARRIS, supra note 59, at 164-65 (describing the suit, describing Rev. Maury's school at which he taught Jefferson, Madison, and Monroe, and noting that "the great geographer Matthew Fontaine Maury" was Rev. Maury's grandson); DIANA FONTAINE CORBIN, A LIFE OF MATTHEW FONTAINE MAURY 7, 13 (2008 reprint of 1888 edition) (noting that Matthew Fontaine Maury was the grandson of Rev. James Maury, and that Matthew Fontaine Maury "married his first cousin (the daughter of his uncle, Fontaine Maury) in Fredericksburg, Virginia"), limited preview available at http://books.google.com/books?id=pI-blhKrdKQC.

142. See infra note 146.

143. Butterfield, supra note 2, at 185. According to Butterfield, the author of the letter was "Captain Joseph Spencer, a Baptist who had suffered imprisonment during the persecutions that Madison himself had witnessed, and a Revolutionary officer." Id. The editors of Madison's papers express uncertainty and suggest that the author might be either the Revolutionary officer or the persecuted minister or perhaps neither. 10 PAPERS OF JAMES MADISON, supra note 12, at 542 n.5. Robert Alley says that "[t]he identity of Spencer is not known." Alley, supra note 141, at 294. It seems unlikely that a Baptist minister (or former minister) would refer to the Baptists as Spencer does in the letter, apparently as part of the "we[a]ker clas[s]," or would refer to the "Pre[a]chers of that Society," as if he were completely separate from it. See infra text accompanying notes 144-45.

144. Letter from Joseph Spencer to James Madison, supra note 140, at 541. 
would become friends to it, that body of people has become Very formible in pint of Elections, as I can think of no Gentln. of my Acquaintance so Suitible to the task as your Self I have taken the liberty to Request it of you, Several of your Connections in Orange Joines me in opinion, thinking it would Answer a Valuable purpus for I am Cartain that pople Relye much on your integerity \& Candure, Mr. Leeland \& Mr. Bledsoe and Sanders are the most publick men of that Society in Orange, therefore as Mr. Leeland Lyes in your Way home from Fredericksburg to Orange would advise you'l call on him \& Spend a few Howers in his Company ... my fears are that Except you \& yr. friends do Exerte yr. Selves Very much youl not obtain yr. Election in Orange Such are the predegeses of the people for in short there is nothing so Vile, but what the Constitution is charged with, hope to See you in Orange in a few days. ... ${ }^{145}$

The letter from Leland to Barbour, a copy of which Spencer included with his letter to Madison, contained ten trenchant objections to the Constitution. ${ }^{146}$ Barbour had solicited the letter from Leland, ${ }^{147}$ and apparently Leland had sent it to Barbour by way of Spencer, who had retained a copy, which Spencer then enclosed for Madison's review:

[I]n Clos'd youl Receive his [Leland's] objections which was Sent by me to, Barber, a Coppy I tooke, this copy was first Design'd for Capt Walker, but as I hoped youl be in this state in a few days thought proper to send to you, by which means youl be made Acquainted with their objections \& have time to Consider them should you think it an Object worth yr. Attention. ... ${ }^{148}$

As the editors of Madison's papers point out, "Leland believed the new plan of government was insufficiently republican and was particularly critical of the omission of a bill of rights and a specific

145. Id. (spelling and grammar left as in original).

146. Copy of Letter from John Leland to Thomas Barbour (undated), enclosed with Letter from Joseph Spencer to James Madison, supra note 140. Butterfield sets out the entire text of the copy of Leland's letter. Butterfield, supra note 2, at 187-88. See 10 PAPERS OF JAMES MADISON, supra note 12, at 541 n.2 (stating that Leland's letter is printed at 4 DOCUMENTARY HISTORY OF THE CONSTITUTION 526-29). High quality, legible images of the copy of Leland's letter are available at the Library of Congress website. See http://memory.loc.gov/master/mss $/ \mathrm{mjm} / 03 / 0300 / 0315 \mathrm{~d} . j \mathrm{pg}$ (page 1); http://memory.loc.gov/master/mss/mjm/03/0300/0316.jpg (page 2); http://www.loc.gov/ exhibits/religion/rel06.html (includes links to images with slightly less resolution but background color that improves legibility).

147. Butterfield, supra note 2, at 187 (quoting copy of Leland's letter to Barbour: "Sir, According to your Request, I have sent you my objections to the Foederal Constitution, which are as follows. ...").

148. Spencer, supra note 140, at 541 (spelling and grammar left as in original). 
guarantee of religious liberty." 149 Here are Leland's three most important objections, the first, eighth, and tenth:

$1^{\text {st. }}$ There is no Bill of Rights, whenever a Number of men enter into a state of Society, a Number of individual Rights must be given up to Society, but there should be a memorial of those not surrendred, otherwise every natural \& domestic Right becomes alianable, which raises Tyranny at once, and this is as necessary in one Form of Government as in another.

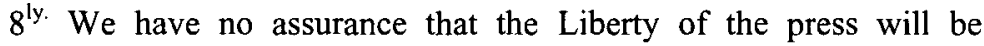
allowed under this Constitution.

$10^{\text {ly. }}$ What is clearest of all-Religious Liberty, is not sufficiently secured, No religious test is Required as a qualification to fill any office under the United States, but if a Majority of Congress with the President favour one System more than another, they may oblige all others to pay to the support of their System as much as they please, and if Oppression does not ensue, it will be owing to the Mildness of Administration and not to any Constitutional defence, and if the Manners of People are so far Corrupted, that they cannot live by Republican principles, it is Very Dangerous leaving Religious Liberty at their Mercy. ${ }^{150}$

Madison had not taken advantage of the opportunity to seek election as a convention delegate from a county other than his home county of Orange. ${ }^{151}$ It could have been expected that Orange County would be "safely Madisonian." 152 However, given the voting strength of the Baptists in Orange County, Madison was now seriously at risk of being excluded from the convention unless he could overcome Leland's well-

149. 10 PAPERS OF JAMES MADISON, supra note 12, at $541 \mathrm{n} .2$.

150. Copy of Letter from John Leland to Thomas Barbour, supra note 146.

151. See Letter from Henry Lee to James Madison, in 10 PAPERS OF JAMES MADISON, supra note 12, at 340 ("If you think you may fail in orange[,] several countys in Kentucky would on application by letr. elect you."). Note that at this time the Kentucky counties were still part of Virginia. See Kentucky, in CONCISE DICTIONARY OF AMERICAN HISTORY, supra note 16, at 515 .

152. KETCHAM, supra note 75 , at 266 ; see also ROBERT A. RUTLAND, JAMES MADISON: THE FOUNDING FATHER 34 (1987) (noting, with respect to ratification convention election, "[o]rdinarily Madison depended on his neighbors to see that he was elected without the bother of coming home, but warning letters told of rising opposition in Orange County"). 
formed objections. ${ }^{153}$ It would thus have made perfect sense for Madison to take Spencer's advice and visit Leland on the way to Orange. Any other approach would be dangerous for Madison, for the successful ratification of the Constitution by Virginia, and for the success of the Constitution itself.

By this time Madison may also have heard that on March 7, 1788, the Baptist General Committee had considered "[w]hether the new Federal Constitution... made sufficient provision for the secure enjoyment of religious liberty," and had "agreed unanimously, that, in the opinion of the General Committee, it did not."154 Leland almost certainly had a strong hand in that determination. ${ }^{155}$ Perhaps the only way to blunt the statewide effect of the Committee's resolution would be to change the mind of the key figure.

But did Madison actually meet with Leland on his way back to Orange? Madison biographer Irving Brant suggestively notes Spencer's recommendation that Madison meet with "an influential Baptist leader" but is silent on whether the meeting occurred. ${ }^{156}$ Eminent church historian Edwin Gaustad, at least somewhat of an expert on Leland, included the meeting in the original edition of $A$ Religious History of America, ${ }^{157}$ but when Leigh Schmidt prepared the revised edition, Schmidt omitted the story, along with all mention of Leland, perhaps indicating skepticism on the part of Schmidt as to whether a meeting

153. See LABUNSKI, supra note 57 , at 44.

154. SEMPLE, supra note 38 , at 102 . Semple's text gives the date as March 7, 1778, but the context shows that the year was 1788. In Semple's chronological exposition, the description of the March 7 meeting follows the description of an August 10, 1787 meeting and precedes the description of an August 11, 1788 meeting. The description of the March 7 meeting also refers to "the new Federal Constitution, which had now lately made its appearance in public." Id.; see also ESTEP, REVOLUTION WITHIN THE REVOLUTION, supra note 12, at 162 (giving a date of March 7, 1788 for the meeting); 10 PAPERS OF JAMES MADISON, supra note 12, at $541 \mathrm{n} .2$ (editorial note) (same).

155. See SEMPLE, supra note 38 , at 103 . It is nearly certain that Leland attended the March 7 meeting; at that meeting he was appointed to an important role (liaison with northern Baptists, in hopes of perhaps creating a committee with national representation). See id. William Estep argues convincingly that at least by the time of the August meeting of the Committee, "it was quite evident that Leland had emerged as the most forceful leader among his peers." See ESTEP, REVOLUTION WITHIN THE REVOLUTION, supra note 12 , at 163 . Note that the next year Leland drafted the Committee's congratulatory letter to President Washington. Butterfield, supra note 2, at 194-95.

156. 3 BRANT, supra note 88, at 188.

157. EDWIN S. GAustad, A Religious History OF AMERICA 119 (1966) (perhaps giving Leland too much credit by saying he "headed the group opposing ratification of the Constitution because of its lack of specific guarantees for religious freedom" and saying that Leland's change of mind made ratification in Virginia "a virtual certainty"); see supra notes 12, 83 (referencing an article and a lecture by Gaustad with Leland as major subject). 
took place. ${ }^{158}$ Richard Labunski's recent detailed study, James Madison and the Struggle for the Bill of Rights, ${ }^{159}$ describes Madison as realizing that he needed "to get home to talk to Leland and others who had serious concerns about the proposed Constitution," 160 but does not describe any actual meeting with Leland in connection with the March 24, 1788, election. ${ }^{161}$ Labunski does comment, in connection with Madison's election to the First Congress, that "Reverend Leland had been helpful in securing Madison's election to the ratifying convention." "162 Most skeptical of all, Robert Alley says "there is reason to reject as improbable any meeting at all with Leland prior to the March 24th election."163 Alley argues that " $[t]$ here is no evidence from Madison or anyone during his lifetime to prove that he met with John Leland," 164 and relies on Madison's failure to mention any such meeting in his March 25th letter to Eliza Trist. ${ }^{165}$ Yet Alley states that " $[t]$ his in no way diminishes Leland's important support for Madison's election,"166 perhaps suggesting that Madison persuaded Leland when he spoke publicly to the assembled voters on March 24, and that Leland threw his support to Madison then and there.

However, most historians who have written on the subject believe the meeting took place, and the evidence, on balance, supports that view. Butterfield confidently says that, after Madison received Spencer's letter with Leland's objections, "[t]here followed a meeting between Madison and Leland...."167 Butterfield adds that "there is nothing beyond circumstantial evidence to prove that it really happened, and much that has been written about it is pure folklore," 168 but in the end he concludes that "[t]here can be no question" but that the meeting actually occurred. ${ }^{169}$ Ralph Ketcham found Butterfield's argument "thoroughly

158. See Edwin S. Gaustad \& Leigh Schmidt, The Religious History of America (rev. ed. 2002).

159. LABUNSKI, supra note 57.

160. Id. at 44 .

161. See id. at 46-47.

162. Id. at 165 .

163. Alley, supra note 141, at 296. Butterfield also cites the 1907 view of a historian of Orange County, who, in response to a particularly fanciful 1881 account in Harper's Monthly, "declared the story perfectly preposterous." See Butterfield, supra note 2, at 190.

164. Alley, supra note 141 , at 295.

165. Id. at 296; see Letter from James Madison to Eliza Trist (March 25, 1788), in 11

PAPERS OF JAMES MADISON, supra note 12, at 5-6.

166. Alley, supra note 141, at 296.

167. Butterfield, supra note 2, at 188.

168. Id. at 188-89.

169. Id. at 190. 
convincing"170 and thus recounts the meeting in his biography of Madison, as does William Lee Miller in two books (though without citing authority). ${ }^{171}$ More recently, Paul Finkelman understatedly concludes that "[o]n March 22 Madison probably met with Rev. John Leland," but then argues that the meeting was "critical" to Madison's election and also "critical for Madison's eventual support for a bill of rights." 72 According to Nathan Hatch, "There is strong evidence that James Madison personally sought his [Leland's] support for the federal Constitution, which Leland had first opposed."173 Stuart Leibiger is convinced that "Madison followed Spencer's advice and met Leland, about March 22, somewhere between Fredericksburg and Orange. Exactly what transpired has been obfuscated by local myth, but it is clear that Madison overcame Leland's doubts about the Constitution and gained his support in the campaign.",174

Consider the evidence, almost all of which is recounted by Butterfield (though Butterfield does not use all of it in his argument that the meeting occurred). First, Madison had motive and opportunity. Madison knew that failure to meet with and persuade Leland could be fatal to Madison's candidacy and perhaps to Virginia's ratification of the Constitution. ${ }^{175}$ And, as Spencer noted, it would be easy for Madison to stop and see Leland on the trip from Fredericksburg to Orange. ${ }^{176}$

170. Ketcham, supra note 83, at 195 n.47; see also Ralph L. Ketcham, The Dilemma of Bills of Rights in Democratic Government, in THE LEGACY OF GEORGE MASON 29, 40 (Josephine F. Pacheco ed., 1983) (stating that Madison met with Leland, his "old friend," and agreed to support post-ratification addition of a bill of rights in exchange for Leland's "withdraw[ing] his opposition to the Constitution, a trade-off that did much to assure Madison's election to the Virginia convention").

171. KeTcham, supra note 75, at 251; William LeE Miller, The Business OF MAY NeXT: JAMES MADison AND THE Founding 194 (1992); William LeE Miller, The First LIBERTY: AMERICAN'S FOUNDATION IN RELIGIOUS FREEDOM 111, 177 (rev. ed., 2003).

172. Finkelman, supra note 12, at 323, 324; see also Paul Finkelman, Turning Losers into Winners: What Can We Learn, If Anything, from the Antifederalists?, 79 TEX. L. REV. 849, 864 (2001) (book review) ("However, Madison's long record of supporting religious liberty and his sincere empathy for Leland's concerns, convinced the minister to support Madison for the Virginia Convention.").

173. HATCH, The DEMOCRATIZATION OF AMERICAN Christianity, supra note 12 , at 96; Hatch, The Democratization of Christianity and the Character of American Politics, supra note 12, at 109.

174. Stuart E. Leibiger, Founding Friendship: George Washington, James MADISON, AND THE CREATION OF THE AMERICAN REPUBLIC 92 (2002); Leibiger, supra note 141 , at 452 .

175. See supra text accompanying notes 106-22, 126-34, and 138-55; $c f$. Butterfield, supra note 2, at 185 (noting Spencer's letter to Madison, supra note 140, that urged Madison to meet with Leland, and stating that "at Fredericksburg [Madison] was greeted with a letter than caused him to do some last-minute and very important canvassing").

176. See supra text accompanying note 145 . 
Second, it seems that Leland developed an expectation that Madison would stop and speak with him when passing through. When Leland wrote to Madison less than a year later to congratulate him on his election to the First Congress, Leland expressed such an expectation: "I take the Liberty of writing thus to you, lest I should not be at Home when you pass by on your Way to Congress." 177 This expectation would be explained if, on his way to Orange for the March 24 election, Madison stopped to see Leland.

Third, the results of the election show that Madison took some decisive action. Madison scored a landslide victory (and the other federalist candidate, James Gordon, Jr., did almost as well). Here are the totals:

$\begin{array}{ll}\text { James Madison (federalist) } & 202 \\ \text { James Gordon, Jr. (federalist) } & 187 \\ \text { Thomas Barbour (antifederalist) } & 56 \\ \text { Charles Porter (antifederalist) } & 34^{178}\end{array}$

Two delegates were to be chosen, and it seems likely that each voter thus could vote for two candidates. The total number of votes cast was 479 . Half that would be $2391 / 2$. Allowing for the likelihood that a few voters may have voted only for one candidate, there likely were about 250 voters, of whom 202 voted for Madison. It seems Madison thus was supported by about $80 \%$ of the voters, an overwhelming majority. Given the perilous state of Madison's candidacy only a few days before, "the election results . . . are proof," as Carl Esbeck notes, "that something had happened to sway the Baptists to Madison's side."179 Something certainly happened to change Leland's mind so that he actually voted for Madison; Leland tells us that he "was in the vigor of [his] life when the national constitution was formed, and gave [his] vote for a friend to its ratification, and ha[s] never repented it." 180

177. Letter from John Leland to James Madison, supra note 80 , at 443 ; see Butterfield, supra note 2, at 192.

178. 3 BRANT, supra note 88 , at 188 ; LABUNSKI, supra note 57 , at $47 ; 11$ PAPERS OF JAMES MADISON, supra note 12, at $6 \mathrm{n} .2$ (editorial note); see Butterfield, supra note 2, at 191-92.

179. Esbeck, supra note 12, at 1500; see Butterfield, supra note 2, at 191-92. Esbeck suggests that Madison won the election by only fifteen votes, because he had only that number more than Gordon. Id. But two candidates were to be elected, and Madison had 146 more votes than the third place candidate. Both federalists won easily.

180. Leland, Address Delivered at Dalton, Massachusetts, January 8, 1831, in WRITINGS, supra note 12, at 605 . 
Fourth, Madison did not arrive as expected for a dinner on March 22. ${ }^{181}$ As Butterfield notes, "It is certainly plausible to suppose that the reason Madison did not keep to his schedule and disappointed his friends on the $22 \mathrm{~d}$ was his decision to go to Leland and remove the Baptist leader's doubts about the Constitution." 182 That could be consistent with Madison's March 25 letter to Eliza Trist, in which he says that " $[t]$ he badness of the roads \& some other delays retarded the completion of my journey. ..."183

Fifth, as Butterfield points out, "the tradition concerning [the] meeting and its results was alive and vigorous at the time of Madison's death." "184 Leland, who died in January, 1841, outlived Madison by three and a half years, ${ }^{185}$ and thus the tradition was established well within Leland's lifetime. That tradition-perhaps with additional information from James Madison's brother William ${ }^{186}$-is confidently reported in a July, 18, 1836, public eulogy of Madison by John Strode Barbour

181. Butterfield, supra note 2, at 191.

182. Id.

183. Madison, supra note 165 , at 5 . Alley seems to think that had one of those delays been the result of a meeting with Leland, Madison would have so explained to Mrs. Trist. See Alley, supra note 141, at 295-96. But the letter to Mrs. Trist is very short, and we do not know Mrs. Trist's view of the Baptists. Madison noted that he was "so taken up with company" that he could not write more. Madison, supra note 165 , at 5 . In addition, Madison was uncomfortable with campaigning and may not have wanted to go into all the details. Madison's letter does suggest that the electoral victory was due to his speech on election day or to "the exertion of the fæederalists," perhaps to the exclusion of a personal meeting with Leland. Id. But Madison may have in modesty included his conversation with Leland within what he called "the exertion of the foderalists," or perhaps that phrase was meant to include Leland's exertions for Madison on election day after Madison previously convinced Leland to support the Constitution. Id.

184. Butterfield, supra note 2, at 190; see also 10 PAPERS OF JAMES MADISON, supra note 12 , at 542 n.4. The editors of the PAPERS state that "[a]lthough accounts of JM's famous meeting with Leland are fanciful, the tradition is strong that such a meeting did in fact occur, probably on 22 Mar. According to this tradition, JM persuaded Leland to change his mind on the Constitution and thereby gained Baptist support on election day." Id. The editors appear to be saying that the accounts of exactly what happened at the meeting are fanciful, not that it would be fanciful to think that the meeting actually took place.

185. Madison died June 28, 1836. KetChaM, supra note 75, at 669-70. Leland died January 14, 1841. Butterfield, supra note 2, at 240.

186. See Butterfield, supra note 2, at 191 n.87. In the eulogy, Barbour noted that, in the struggle to secure religious liberty in Virginia, "the sect denominated Baptists took the foremost part." Barbour said that he "allude[d] to their agency in this noble and holy work at the instance of the only living brother of the illustrious man to whose memory we have now assembled to do honor." John S. Barbour, Oration on the Life, Character, and Services of James Madison, DaILY NAT'L INTELligENCER, Aug. 2, 1836 (Washington, D.C.), microform reproduction by Library of Congress Photoduplication Service (Vol. XXIV, No. 7323) (microfilm reel containing Feb. 3 through Sept. 26, 1836 issues) (pagination unclear on copies from microfilm). 
(lawyer, Virginia state legislator, and member of Congress, ${ }^{187}$ not to be confused with the Thomas Barbour who opposed Madison in the March 24, 1788, election). The eulogy was printed two weeks later in a Washington newspaper, ${ }^{188}$ which, as noted below, apparently was available in Massachusetts, though it is difficult to find now. Here is Butterfield's description of the eulogy:

Barbour discussed at some length the close alliance between Madison and the Baptists and said that his [Madison's] election to the Virginia ratifying convention in 1788 was owing to his changing the minds of two Baptist ministers on the eve of the election. "The celebrated John Leland was one of them ... and I speak but the voice of faithful tradition in saying that these changes were decisive in the election." $" 189$

Alley quotes Barbour as saying that Madison's "soft and assuasive and lucid elocution changed two ministers of the Gospel of the Baptist Church on the day preceding the election and that conversation carried him to the Convention. The celebrated John Leland was one of them."

Sixth, and finally, two credible sources-George N. Briggs, and Maria Newton Marshall-directly confirm that such a meeting took place. $^{191}$ Briggs served in Congress, then became Governor of Massachusetts, and finally served as a state court judge in Massachusetts. ${ }^{192}$ Briggs was a young boy when he first met Leland, and he seems to have stayed in touch with Leland until shortly before

187. See "Barbour, John Strode (1790-1855)," in the Biographical Directory of the United States Congress, http://bioguide.congress.gov/scripts/biodisplay.pl?index= B000128 (last visited Aug. 20, 2008).

188. Barbour, supra note 186.

189. Butterfield, supra note 2, at 190-91 (accurately quoting Barbour's oration as printed in the Daily National Intelligencer newspaper); see supra note 186.

190. Alley, supra note 141 , at 295. Alley cites the 1810 edition of Semple's A HISTORY OF THE RISE AND PROGRESS OF THE BAPTISTS IN VIRGINIA (see supra note 38 for citation to a later edition) for this 1836 eulogy, but of course that must be a mistake. The author was not able to locate the eulogy in any available edition of Semple's HISTORY. The oration as reprinted in the Daily National Intelligencer includes the language quoted by Alley, though with slightly different capitalization and punctuation. See Barbour, supra note 186.

191. See infra text accompanying notes 193-202 and 208-11.

192. See "Briggs, George Nixon (1796-1861)," in the Biographical Directory of the United States Congress, http://bioguide.congress.gov/scripts/biodisplay.pl?index= B000830 (last visited Jan. 25, 2009); Commonwealth of Massachusetts, "Alphabetical List of Governors," http://www.mass.gov/lib/facts/alphabeticallistofgovernors.doc. (last visited Aug. 20, 2008); Commonwealth of Massachusetts, "George Nixon Briggs (17961861)," available at www.mass.gov (search for "George Nixon Briggs" and select the first item returned by the search) (last visited Aug. 20, 2008). 
Leland's death in $1841 .^{193}$ In an 1857 letter written for and printed in the Annals of the American Baptist Pulpit, Briggs shared his recollections of Leland, including his recollection of a lengthy conversation he had with Leland in about $1837 .{ }^{194}$ Briggs "had recently seen in the public prints an extract from" Barbour's eulogy. Briggs told Leland

that Barbour had said that the credit of adopting the Constitution of the United States properly belonged to a Baptist clergyman, formerly of Virginia, by the name of Leland; and he reached his conclusion in this way-he said that if Madison had not been in the Virginia Convention, the Constitution would not have been ratified by that State ... and that it was by Elder Leland's influence that Madison was elected to that Convention. ${ }^{195}$

Leland responded, according to Briggs, by denying that he deserved so much credit. ${ }^{196}$ Leland explained that he had been on Patrick Henry's side in the argument over ratification of the Constitution--the side that insisted on amendments before ratification. ${ }^{197}$ In fact, as Briggs recalled the conversation, Leland said that he, Leland, was the antifederalist candidate opposing Madison in the ratifying convention election. ${ }^{198}$ "Orange was a strong Baptist County; and his [Leland's] friends had an undoubting confidence in his election. Though reluctant to be a candidate, he yielded to the solicitations of the opponents of the Constitution, and accepted the nomination."199 But Madison visited Leland the day before the election. ${ }^{200}$ "Mr. Madison spent half a day with him, and fully and unreservedly communicated to him his opinions. ..."201 The next day

they met, and with them nearly all the voters in the County of Orange. ... "Mr. Madison," said the venerable man [Leland], "first took the stump, which was a hogshead of tobacco, standing on one end. For two hours he addressed his fellow-citizens in a calm, candid and statesman-like manner, arguing his side of the case, and fairly meeting and replying to the arguments, which had been put forth by

193. Letter from G.N. Briggs (April 15, 1857), in SpRaGuE, supra note 44, at 177, passim.

194. Id. at 178-80. Briggs said the conversation took place "three or four years before [Leland] died" and that Mrs. Leland was present. John Leland died in January, 1841, and Sally Leland died in October, 1837. SPRAGUE, supra note 44, at 176-77. Thus the conversation probably took place in 1837 , some time before October.

195. Id. at $178-79$.

196. Id. at 179.

197. Id.

198. Id.

199. Briggs, supra note 193, at 179.

200. Id.

201. Id. at 180 . 
his opponents, in the general canvass of the State. Though Mr. Madison was not particularly a pleasing or elegant speaker, the people listened with respectful attention. He left the hogshead, and my friends called for me. I took it -and went in for Mr. Madison; and he was elected without difficulty."202

This report agrees in some respects with the events as described by Madison in his letter to Mrs. Trist. In that letter Madison says he was "obliged ... to mount ... the rostrum before a large body of people, and to launch into a harangue of some length in the open air. ..."203 The hogshead-a barrel-instead of a proper rostrum was perhaps a humorous flourish by Leland. And the report confirms that Madison and Leland met the day before the election. Drama is heightened in the story by Leland's waiting to endorse Madison publicly until after Madison's speech, even though it is unlikely Madison would have persuaded Leland with a two-hour speech if he had not been able to do so the previous day in a half-day-long private conversation.

The real difficulty is that Briggs's report puts Leland in Thomas Barbour's (or Charles Porter's) role as the antifederalist candidate. ${ }^{204}$ The detail given about how Leland was reluctant to serve as a candidate but finally agreed makes it seem that this was a key part of the conversation, as reported by Briggs. ${ }^{205}$ Can we trust the general thrust of the report if it is wrong on such a basic point?

Consider a possible explanation. Perhaps, after twenty years, Briggs confused several aspects of Leland's description of the event. Leland may have explained to Briggs that Madison was reluctant to be a candidate, as Leland probably knew; Madison probably would have made that point to Leland in the course of a long conversation (or may well have said it in his election-day speech). Leland may also have explained to Briggs that he, Leland, was in some way leading the opposition to Madison; after all, Leland had gone to the trouble of writing up his ten objections for Thomas Barbour and had been involved-probably centrally-in the Baptist General Committee's emphatic rejection of the Constitution. ${ }^{206}$ And Leland may have pointed

202. Id. In an insightful article on Madison and legislative chaplains, Andy Olree mentions Madison's meeting with Leland and accepts the view that Leland was the opposing candidate. Andy G. Olree, James Madison and Legislative Chaplains, $102 \mathrm{Nw}$. U.L. ReV, 145, 170-71 (2008) (citing 1 Anson Phelps Stokes, Church and STATE IN THE UNITED STATES 354 (1950)). Butterfield, Brant, Ketcham, Labunski, and the editors of Madison's Papers all agree that Barbour and Porter were the opposing candidates. See supra note 178; КетCHAM, supra note 75 , at 251 .

203. Letter from James Madison to Eliza Trist, supra note 165, at 5.

204. See supra text accompanying notes 198-200.

205. See id.

206. See supra text accompanying notes 140-55. 
out that the Baptist voting strength in Orange County would make election of antifederalists very likely, unless the Baptists could be convinced to support the Constitution. ${ }^{207}$ At a twenty-year remove, Briggs may have confused together those explanations and come away thinking that Leland was the reluctant candidate with very strong support.

Maria Newton Marshall-writing in 1900 in the first incarnation of the Green $\mathrm{Bag}^{208}$-confirms that Madison and Leland met before the March 24, 1788, election. ${ }^{209}$ But it is hard to know for sure just what she is claiming, with respect to eye-witness testimony. She recounts the opposition to ratification of the Constitution, especially opposition by religious nonconformists, and says:

These facts recall an incident at this stage of Madison's career, of undoubted authenticity, and familiar to many of the older residents of Orange County, who have gathered, as is their privilege, from that period which is their own past and was [apparently as of the beginning of the ratification struggle] Madison's future, many a bit of his personal history so far unchronicled. The writer gives the incident as related to her by her father, himself an octogenarian,- and by his friend and contemporary, a native and life-long resident of Orange County. $^{210}$

The most reasonable interpretation of this passage is that at the time Marshall was writing (1900 or perhaps 1899), there were older residents of Orange County who remembered Madison. Madison lived until 1836, and thus anyone 70 or older might have remembered him and perhaps events involving him. Such events would thus have been from the older residents' own past, but they could have been in the future-as much as forty-eight years in the future-from the standpoint of a Madison engaged in the ratification struggle in 1788. That makes sense of Marshall's creative prose. But it is highly doubtful that anyone alive in 1900 could have witnessed and remembered an incident from 1788 .

Thus, when Marshall says that she will provide the account of the meeting in 1788 "as related to her by her father, himself an octogenarian," 211 she probably means that her father is, as of the time of

207. See supra text accompanying note 153.

208. Maria Newton Marshall, An Episode in Madison's Career, 12 GREEN BAG 339, 340 (1900), available on HeinOnLine; see Butterfield, supra note 2, at 190 (describing Marshall's story as "somewhat more circumstantial and plausible" than Briggs's account). The Green Bag was rejuvenated in 1997 after an 83-year hiatus. See http://www.greenbag.org/about.php.

209. Marshall, supra note 208.

210. Id. at 340 .

211. Id. 
her writing, in his eighties. That would place his date of birth between 1810 and 1820 . He would perhaps remember events involving Madison, but of course not an event that took place in 1788, before he was born. Instead, he would have heard stories about the Madison of the 1780sincluding stories about the 1788 meeting between Madison and Lelandfrom older relatives and neighbors who could have been eyewitnesses.

As a result, Marshall's story needs to be treated with care. She is telling the story as she remembers it being told to her by her father, who told it to her as he remembered it being told to him by those who claimed to be eyewitnesses. The story apparently grew with the telling. Leland is now himself one of the preachers jailed in Culpeper County, and Leland supposedly blames Madison for his imprisonment, none of which is true. With the story thus embellished, Leland has a stronger motivation to oppose Madison and a more personal stake in protecting religious liberty. Madison has serious reason to doubt that Leland will be open to persuasion. A crowd gathers to witness the epic contest when Madison and Leland meet by chance and commence verbal battle. Madison's ultimate victory in persuading Leland to withdraw his opposition becomes an even greater achievement, and Leland's willingness to change his mind shows even greater nobility.

Nevertheless, because Marshall's father was old enough to remember Madison and to remember what was being said about Madison during Madison's lifetime, he would not be likely to accept something made up out of whole cloth. The tradition, at least, of a meeting having occurred between Madison and Leland would likely have to have already been current by the time of Madison's death for it to seem plausible to Marshall's father. And the heart of the story likely would have had to be true for it to gain currency, while so many still lived who remembered 1788 clearly, and who perhaps still corresponded with Leland. It seems reasonable, then, to treat Marshall's story as providing some evidence that the meeting did take place, and that Leland was persuaded, the day before the election, to support Madison.

The evidence seems persuasive to your author, though perhaps Butterfield overstates the case when he says that " $[t]$ here can be no question" but that the meeting actually occurred. ${ }^{212}$ On the other hand, Butterfield's very careful study of Leland--and Butterfield's background in the period (as of the 1952 publication date for the article) through his work editing Jefferson's papers and his work at the Williamsburg Institute-may give him the best perspective on this issue. At the very least, it seems probable that Madison met with Leland before the election

212. Butterfield, supra note 2, at 190. 
and persuaded Leland to support Madison's candidacy, which otherwise likely would have failed. ${ }^{213}$

On June 25, 1788, the Virginia convention ratified the Constitution on a vote of 89 to 79 , after rejecting, on a vote of 80 to 88 , a motion to ratify it conditionally with amendments. ${ }^{214}$ In the end, Madison adopted the approach that had been successful in Massachusetts: he promised those delegates who sought amendments that after ratification their proposals for amendments would be considered and that "those amendments which were 'not objectionable, or unsafe' could be 'subsequently recommended' after ratification." 15 Without Madison at the ratifying convention to oppose Patrick Henry, it seems likely the result would have been different (though Madison still could have assisted behind the scenes). Here is Brant's description of Madison's central and crucial role:

In guiding the Constitution to victory, Madison won the greatest forensic battle of his life, over the most formidable adversary he ever faced, for the greatest stakes in national welfare. His leadership was universally recognized. ... Patrick Henry knew who his adversary was. From June 11, the day Madison recovered from his illness, Henry made seventeen speeches in specific reply to him, fifteen in reply to all other delegates combined. The full extent of this leadership was not measured by his own work on the floor, extensive and effective as it was. Except for the arguments of Pendleton and Marshall on the judiciary, virtually every affirmative utterance from any source bore the stamp of Madison's thought.... Superior reasoning was not enough. He had to pile up an extraordinary margin of logic to cancel the opposing eloquence.

... He won by placing every disputed issue before the convention in terms so clear and logical, offered with such sincerity and fairness, that they held their ground against the passionate oratory, the distortions and exaggerated alarms of Henry, Mason, and Grayson.

... Under Henry's inspiration, the antifederal arguments were improvised assaults of the passions upon the intellect. In a quick-

213. See supra text accompanying notes $125-32,138-55$; text accompanying note 180 (quoting Leland's own statement that he "gave [his] vote for a 'friend' [Madison] to [the Constitution's] ratification").

214. 3 BRANT, supra note 88 , at 226-27; KETCHAM, supra note 75 , at 263-64. Ratification with prior amendments would have been conditional on agreement by the other states to the exact same amendments, agreement unlikely to be obtained. See Madison's Speech of June 24, 1788, 11 PAPERS OF JAMES MADISON, supra note 12, at 172; Finkelman, supra note 12, at 326-27.

215. Finkelman, supra note 12 , at 327; see id. at 324-25. 
acting convention they might have carried the field. In twenty-four days they broke down under the greatness of the national crisis and the cumulative force of Madison's steady appeal to reason. ${ }^{216}$

Even so, the outcome was in doubt nearly to the end. On June 23, 1788, Madison wrote to Washington, "We calculate on a majority, but a bare one. It is possible nevertheless that some adverse circumstances may happen.",217

Labunski aptly describes the importance of Virginia's ratification:

Virginia had to be part of the new government for it to survive its infancy. Virginia was the most important state politically in the South, if not the nation. It was by far the largest state geographically, comprising what is today Virginia, West Virginia, and Kentucky. It had almost twice as many residents as the next largest state. ...

... If Virginia failed to ratify in June 1788 , and was left out of the nation at its beginning, no Virginians would be eligible for office in the first national government-not even George Washington. Any new federal government without Washington as chief executive would be sorely lacking in credibility and trust. ${ }^{218}$

In addition, news of Virginia's ratification influenced New York to ratify the Constitution in July, by a close vote of 30-27 in its convention. ${ }^{219}$ Hamilton had written to Madison on June 25 that the chances of ratification in New York were "infinitely slender, and none at all if you go wrong" (that is, if ratification failed in Virginia). ${ }^{220}$

Thus, Baptist publications and websites proudly proclaim the key role Leland played in ratification of the Constitution. ${ }^{221}$ There is truth in

216. 3 BRANT, supra note 88 , at $227-28$.

217. Letter from James Madison to George Washington (June 23, 1788), in 11 PAPERS OF JAMES MADISON, supra note 12, at 168 (bearing date of "June Tuesday 25" but actually written, per PAPERS editors, on Monday, June 23).

218. LABUNSKI, supra note 57 , at 27-28.

219. See 3 BRANT, supra note 88 , at 229; AKHIL REED AMAR, AMERICA's CONSTITUTION: A BIOGRAPHY 312 (2005) ("New Yorkers eventually ratified the [Constitution] in July 1788 only because it was clear that-thanks to ten prior state ratifications-the new ship Constitution was setting sail with or without them."); LABUNSKI, supra note 57, at 121.

220. Letter from Alexander Hamilton to James Madison (June 25, 1788), in 11 PAPERS OF JAMES MADISON, supra note 12, at 179.

221. See, e.g., James H. Sightler, The Separate Baptist Revival and Its Influence in the South, http://www.bible1611.com/EndofAgeMessages/ShubalStearnsSeparate Baptist.htm (2004) (last visited Dec. 10, 2008); John E. Roberts, Real Freedom-A Sermon for Religious Liberty Sunday, http://www.woodbrook.org/sermons/1999/ 990704.htm (1999); (last visited Dec. 10, 2008); Joseph L. Conn, Legacy of Liberty, 57 ChURCH \& STATE 205, 205-06 (October 2004); 3 William CATHCART, United States, The Constitution of; Aid Given by the Baptists in its Adoption, in BAPTIST ENCYCLOPAEDIA 
that boast, but it should be remembered that, but for the initial Baptist opposition, Madison likely would have been elected as a convention delegate with no trouble. ${ }^{222}$

Perhaps, instead, the boast should be that Leland and the Baptists persuaded Madison to look more closely at whether the Constitution should be amended, post-ratification, to include a bill of rights and helped to shape Madison's thinking on that issue. It is not clear what Madison said to Leland to obtain Leland's support, and further speculation as to the details would not be particularly useful. ${ }^{223}$ Perhaps it is enough to say that, to persuade Leland, Madison probably would have had to at least admit the possibility that a bill of rights could be added to the Constitution by post-ratification amendments. Such an admission-when combined with the need for Madison to confront Leland's heartfelt arguments--could have caused Madison's thinking to evolve toward acceptance of the value of a bill of rights, as Paul Finkelman suggests. ${ }^{24}$ It could have helped reconcile Madison to the practical need to promise consideration of post-ratification amendments, a promise that led to ratification in Massachusetts, turned out to be equally effective at the Virginia convention, ${ }^{225}$ and would play such a large role in Madison's election to the First Congress. ${ }^{226}$

\section{MADISON'S ELECTION TO THE FIRST CONGRESS}

Madison defeated Patrick Henry at the Virginia ratifying convention, but Henry still hoped for major revisions to the Constitution (preferably, in his view, by way of a second constitutional convention). ${ }^{227}$ If Madison were in the new federal Congress-either the Senate or the House of Representatives-Madison would oppose major

1181, 1182-85 (photo. reprint 2001 by The Baptist Standard Bearer, Inc.) (Philadelphia, Louis H. Everts, 1881); Click Concepts, CELEBRATE FreEdom (no date available), text and low resolution images of pamphlet or tract available at http://clickconcepts.org/store/celfreeprev.htm (last visited Dec. 10, 2008); see Smith, supra note 11 , at $249-50$.

222. See supra text accompanying note 152 .

223. For views of what Madison probably said to Leland, beyond the accounts described above, see MILLER, THE BUSINESS OF MAY NEXT, supra note 171, at 194 ("Ratify first; amend later."); KETCHAM, supra note 75, at 251 ("In return for Leland's promise to withdraw his objections, Madison reaffirmed what he and other federalists had increasingly agreed to: they would support a bill of rights, including a firm article on religious freedom, as amendments to the Constitution after its ratification.") (emphasis in original); Finkelman, supra note 12, at 323 ("Madison's long record of supporting religious liberty, and his sincere empathy for Leland's concerns, convinced the minister to support Madison for the Virginia convention.") (footnote omitted).

224. Finkelman, supra note 12 , at 324 .

225. See id. at 323-28.

226. See infra text accompanying notes 247-86.

227. See LABUNSKI, supra note 57, at 120-21; 3 BRANT, supra note 88, at 299. 
changes in the new structure of government and would perhaps support minor amendments "to mollify the people." 228 For that reason, and perhaps for revenge, Henry set out to deny Madison a seat in the new federal Congress, first in the Senate, and then in the house where Madison indicated a preference to serve, the House of Representatives. ${ }^{229}$

Henry still had firm control of the Virginia General Assembly, where he was, according to Madison, "omnipotent.",230 At Henry's instigation, the Virginia legislature denied Madison a Senate seat; ${ }^{231}$ as Richard Labunski notes, Henry argued that Madison was "not to be trusted with amendments since [Madison] had declared that not a letter of the Constitution cou'd be spared."232 That was a false charge that would be leveled against Madison repeatedly during the Congressional campaign, especially by one of the antifederalist ratification convention delegates, Joel Early, who apparently was a member of George Eve's Rapidan Baptist church in Culpeper County. ${ }^{233}$

The Virginia elections for the federal House of Representatives were set for February 2, 1789; to ensure Madison's defeat, the Virginia legislature created a gerrymandered Congressional district that included Madison's home county, Orange, along with several heavily

228. See LABUNSKI, supra note 57, at 121.

229. See id. at 120-22, 135-46, 148-52; 3 BRANT, supra note 88, at 236; КETCHAM, supra note 75 , at 275 ; Finkelman, supra note 12, at 334.

230. Letter from James Madison to Thomas Jefferson (Dec. 8, 1788), in 11 PAPERS OF JAMES MADISON, supra note 12, at 384; see LABUNSK1, supra note 57, at 120 . According to George Washington, "the edicts of Mr. H[enr]y are enregistered with less opposition by the Majority of that body [the Virginia Assembly], than those of the Grand Monarch are in the Parliaments of France. He has only to say let this be Law-and it is Law." Letter from George Washington to James Madison (Nov. 17, 1788), in 11 PAPERS OF JAMES MADISON, supra note 12 , at 351 .

231. See Letter from Edmund Randolph to James Madison (Nov. 10, 1788), in 11 PAPERS OF JAMES MADISON, supra note 12, at 338-39; LABUNSK1, supra note 57, at 13638. Madison expected that the antifederalist legislature would refuse to elect him or any other federalist to the Senate. Letter from James Madison to Edmund Randolph (Nov. 2, 1788), in 11 PAPERS OF JAMES MADISON, supra note 12, at 329. (At that time United States Senators were elected by state legislatures as provided in the original text of the Constitution. See U.S. ConST. art I, $\S 3$, cl. 1, amended by U.S. ConST. amend. XVII.)

232. Letter from George Turberville to James Madison (Nov. 16, 1788), in 11 PAPERS OF JAMES MADISON, supra note 12, at 346-47 (emphasis in original); LABUNSKI, supra note 57, at 143. As Brant notes, Henry Lee reported to Madison that "Mr. Henry on the floor exclaimed against your political character \& pronounced you unworthy of the confidence of the people in the station of Senator. That your election would terminate in producing rivulets of blood throughout the land." Letter from Henry Lee to James Madison (Nov. 19, 1788), in 11 PAPERS OF JAMES MADISON, supra note 12, at 356 (quoted in 3 BRANT, supra note 88, at 237). Madison wrote to Jefferson that Patrick Henry had "added . . . a public philippic agst. my federal principles." Letter from James Madison to Thomas Jefferson, supra note 230 , at 384.

233. See infra note 321 . 
antifederalist counties. ${ }^{234}$ To prevent Madison from running in a different, safer district, the Virginia legislature created a one-year district residency requirement (recognized at the time as likely unconstitutional $^{235}$ ) for House candidates. ${ }^{236}$ (Madison chose to honor that requirement and run in his home district, rather than in a more hospitable district, apparently to avoid a fight over the constitutionality of the residency law and to avoid the "question... whether he was elected legitimately."237) Perhaps to keep Madison physically out of Virginia and to make it harder for Madison to win election to the House, Henry supported Madison's reappointment to the Confederation Congress, which would sit in New York. ${ }^{238}$ And then the antifederalists recruited a strong candidate to run against Madison in that district, James Monroe, who was one of Madison's closest friends ${ }^{239}$ and who would succeed Madison as President. ${ }^{240}$

234. LABUNSKI, supra note 57, at 139-40, 148 ("Patrick Henry had done an extraordinary job of creating a Congressional district in the Piedmont area of central Virginia that would be hostile to Madison and his supporters.") (footnote omitted); 3 BRANT, supra note 88, at 238; Letter from George Turberville to James Madison (Nov. 13, 1788), in 11 PAPERS OF JAMES MADISON, supra note 12, at 343-44; Letter from Edward Carrington to James Madison (Nov. 14, 1788), in 11 PAPERS OF JAMES MADISON, supra note 12, at 345-46; Letter from James Madison to Thomas Jefferson, supra note 230, at 384; Letter from Burgess Ball to James Madison (Dec. 8, 1788), in 11 PAPERS OF JAMES MADISON, supra note 12 , at 385 . Ball wrote that " $[t]$ he Counties annexed to yours are arranged so, as to render your Election, I fear, extremely doubtful, the greater no. being Antifederal." Letter from Burgess Ball to James Madison, supra. "According to the political writer 'Decius,' Henry would have put in Cumberland and Prince Edward [Counties] had he thought them necessary" to defeat Madison. 3 BRANT, supra note 88, at 238. Thus, it seems that Patrick Henry thought the district he had created would ensure Madison's defeat without inclusion of additional antifederalist counties.

For a map of the district, which included Orange, Culpeper, Spotsylvania, Louisa, Amherst, Albemarle, Fluvanna, and Goochland Counties, see LABUNSK1, supra note 57, at 149. Labunski points out that several of the original eight counties later were divided, creating four additional counties within the same geographic bounds (Madison, Nelson, Greene, and Rapahannock Counties). Culpeper County is now less than half the size it was in 1789. Id. at 148.

235. LABUNSKI, supra note 57, at 141; Letter from Edward Carrington to James Madison (Dec. 2, 1788), in 11 PAPERS OF JAMES MADISON, supra note 12, at 378-79.

236. LABUNSKI, supra note 57, at 140-41; 3 BRANT, supra note 88, at 238. For offers to help Madison run in safe districts, see Letter from George Turberville to James Madison (Nov. 10, 1788), in 11 PAPERS OF JAMES MADISON, supra note 12, at 340-41; Letter from Edward Carrington to James Madison, supra note 235, at 378; Letter from Rev. James Madison to James Madison (Nov. 22, 1788), in 11 PAPERS OF JAMES MADISON, supra note 12 , at 359-60.

237. LABUNSKI, supra note 57 , at 142.

238. Id.; Letter from George Turberville to James Madison, supra note 236, at 344.

239. KETCHAM, supra note 75 , at 234 . The friendship survived the campaign and ended only with Monroe's death in 1831. See id. at 277, 666 .

240. See LABUNSKI, supra note 57, at 143-44. "Monroe ... had a good military record in the revolutionary war, had been a member of the Confederation Congress, and was an outspoken advocate of amendments" to the Constitution." Leibiger, supra note 
Madison had an "extreme distaste" for "steps having an electioneering appearance."241 When he learned which counties were included with Orange in his home Congressional district, he wrote Jefferson on December 8,1788 , that he thought he would lose even if he returned to Virginia to try to advance his candidacy; returning would "answer no other purpose than to satisfy the Opinions and intreaties of my friends."242 According to Ketcham, Madison considered his prospects "hopeless." 243 Nevertheless, his friends had pressed him to come, and, in the same letter, he told Jefferson that he had decided to leave for Virginia "in a day or two." $244 \mathrm{He}$ arrived in Alexandria on December 18, arrived (or at least planned to arrive) in Fredericksburg en route to Orange on December $26,{ }^{245}$ and apparently arrived in Orange "shortly after Christmas, about a month before the election was to take place." 246

The district had been constructed by Patrick Henry to contain a strong majority of antifederalists-to be "overflowing with antifederalists" dissenters in Louisa and Culpeper counties ... to swell the antifederal

141, at 458. Monroe also had served in the Virginia ratifying convention, see, e.g., KETCHAM, supra note 75 , at 259 , and had been disappointed earlier not to be chosen as one of Virginia's delegates to the Philadelphia Convention, LABUNSKI, supra note 57, at 153.

241. Letter from James Madison to George Washington (Dec. 2, 1788), in 11 PAPERS OF JAMES MADISON, supra note 12, at 377.

242. Letter from James Madison to Thomas Jefferson, supra note 230, at 384 . Madison told Jefferson that after Patrick Henry had arranged for Madison to be denied a seat in the Senate, Henry had "taken equal pains in forming the Counties into districts for the election of Reps. to associate with Orange such as are most devoted to his politics, and most likely to be swayed by the prejudices excited agst. me." Id.

243. KETCHAM, supra note 75 , at 275.

244. See Letter from James Madison to Thomas Jefferson, supra note 230. Friends and associates who urged Madison to return included George Turberville, Alexander White, Burgess Ball, Richard Bland Lee, Andrew Shepherd, and Hardin Burnley. See Letters from those persons to Madison (Nov. 13, Dec. 4, Dec. 8, Dec. 12, Dec. 14, and Dec. 16,1788 ), in 11 PAPERS OF JAMES MADISON, supra note 12 , at $344,380,385,392$, 396, 398. Two friends suggested he not come, Edward Carrington and Edmund Randolph. Carrington later said he was happy Madison had ignored his advice, and Madison wrote to Randolph to say that he would have lost the election had he received Randolph's advice in time to follow it. See Letter from Edward Carrington to James Madison, supra note 235, at 378; Letter from Edward Carrington to James Madison (Feb. 16, 1789), in 11 PAPERS OF JAMES MADISON, supra note 12, at 445; Letter from James Madison to Edmund Randolph (Mar. 1, 1789), in 11 PAPERS OF JAMES MADISON, supra note 12 , at 453 .

245. See Letter from James Madison, Jr. to James Madison, Sr. (Thursday, Dec. 18, 1788), in 11 PAPERS OF JAMES MADISON, supra note 12 , at $400 ; 11$ PAPERS OF JAMES MADISON, supra note 12, at 302 (editorial note).

246. Madison's Election to the First Federal Congress: October 1788-February 1789 (Editorial Note), in 11 PAPERS OF JAMES MADISON, supra note 12, at 301, 302.

247. LABUNSKI, supra note 57, at 140, 146. 
ranks." ${ }^{248}$ Opposition to the Constitution may have been fading, ${ }^{249}$ but antifederalists-even moderate antifederalists like Monroe-still thought some amendments were necessary, including a bill of rights, and so did some federalists. ${ }^{250}$ Baptists considered a bill of rights essential, and there were a lot of Baptists in the Congressional district, ${ }^{251}$ especially in

248. KETCHAM, supra note 75 , at 277.

249. See Letter from James Madison to Thomas Mann Randolph (Jan. 13, 1789), in 11 PAPERS OF JAMES MADISON, supra note 12, at 416.

250. See, e.g., United States v. Emerson, 270 F.3d 203, 244-45, 259 (5th Cir. 2001), cert. denied, 536 U.S. 907 (2002); Kenneth R. Bowling, "A Tub to the Whale": The Adoption of the Bill of Rights, in THE BILL OF RIGHTS AND THE STATES: THE COLONIAL AND Revolutionary ORIGINS OF AMERICAN LiBERTIES 46, 48 (Patrick T. Conley \& John P. Kaminski eds., 1992) (noting that James Monroe, a "moderate Antifederalist," argued for amendments in his campaign against Madison); Finkelman, supra note 12, at 322-28 (noting the demands of antifederalists in Massachusetts and Virginia for amendments); id. at 328-31 (describing Jefferson's views as a supporter of the Constitution who favored addition of a bill of rights); 3 Brant, supra note 88, at 196 (noting that Governor Randolph's statement at the beginning of the Virginia ratifying convention "repeated his desire for amendments, but . . . [that he] threw himself fully into the federal scale").

251. See LABUNSKI, supra note 57, at 163 (noting that Baptists "had a significant presence in Orange and other counties in the district") (footnote omitted); Madison's Election to the First Federal Congress, supra note 246, at 303 (noting that "the Baptists ... were politically active not only in Culpeper but throughout the district"); CHARLES F. JAMES, DOCUMENTARY History OF THE STRUGGLE FOR RELIGIOUS LIBERTY IN VIRGINIA 161 (J.P. Bell Co. 1900), available at http:/books.google.com/books? id= $\mathrm{x} 9 \mathrm{dSNUdQWgcC}$ ("In all these counties there was a strong Baptist sentiment, and in most of them the Baptist element was large enough to hold the balance of power.").

Age, race, and property qualifications for voting eligibility make it difficult to accurately determine Baptist voting strength, but apparently it had been growing quickly. See Buckley, supra note 89, at 42-43; see also LABUNSKI, supra note 57, at 152 (noting that only men twenty-one or older who "own[ed] either fifty acres of property or twentyfive acres with a house" were eligible to vote); Michelle D. Deardorff, Between Freedom and Bondage: Race, Party, and Voting Rights in the Antebellum North, 18 L. \& POL. BOOK REV. 235 (Mar. 20, 2008) (reviewing Christopher Malone, BETWEEN FREEDOM AND BONDAGE: RACE, PARTY, AND VOTING RIGHTS IN THE ANTEBELLUM NORTH (2008)), available at http://www.bsos.umd.edu/gvpt/lpbr/reviews/2008/03/between-freedom-and-bondagerace-party.html (noting that Virginia, in 1762, was the first of the states or colonies to limit voting to whites only). In fact, a revival had broken out within the area of the Congressional district in October, 1787; it lasted until March 1789. During this revival, Leland preached throughout an area "more than twenty miles square"-thus including more than 400 square miles-located in the heart of the Congressional district and encompassing parts of four of the eight counties that made up the district: Orange, Culpeper, Spotsylvania, and Louisa Counties. See Events, supra note 1, at 27. Leland baptized about 400 persons during the revival (300 during 1788), id., and of course Leland was not the only Baptist preacher in the district. Semple reports, for example, that pastor George Eve's Blue Run church in Orange County saw "[m]any precious souls ... enlisted . . . in [its] ranks" in 1788 and 1789. SEMPLE, supra note 38, at 241.

Although Leland suggests that as of 1790 there were about 20,000 Baptists in Virginia out of a total population of roughly 600,000 , he notes that "[ $t]$ he number of communicants [members] compose but a small part of those who commonly attend Baptist worship." As a result, it did not "appear extravagant," according to Leland, "to say that ... there are more people who attend the Baptist worship, than any [other] kind of worship in the state." Virginia Chronicle, supra note 37, at 93, 116-17. That is only 
Culpeper County, ${ }^{252}$ which had a total population almost twice as large as that of any other county in the district ${ }^{253}$ and thus likely would be pivotal. ${ }^{254}$ As Labunski explains, "Baptists would be a crucial constituency"255 that "would play a crucial role in the election."256 Apparently, Madison had a particularly uphill battle in Culpeper county because of French Strother, the highly influential antifederalist who had served Culpeper County in the Virginia legislature for twenty-three years and who would support Monroe vigorously. ${ }^{257}$ What may not generally

one reason why it would be misleading to divide 20,000 by 600,000 and conclude that only $3.3 \%$ of the population was Baptist (or Baptist in sympathy). In addition, the 600,000 figure included children, $i d$. at 93 , many of whom were too young to be baptized members of a Baptist church; thus, the numbers are not directly comparable. Leland's 600,000 figure also included about 276,000 slaves. Leland believed that slaves were entitled to religious freedom, but it is not clear that very many slaves were included among the 20,000 members; thus, again, a $3.3 \%$ figure would be misleading, at least in terms of potential voting power. On the other hand, Leland's 600,000 figure is too low; the 1790 census showed a total Virginia population (not including Kentucky) of almost 750,000 , of whom about 216,000 were free whites over sixteen. See BUREAU OF THE Census, Heads of Families at THE First Census of THE United States Taken IN THE YEAR 1790, at 8 (Washington, Gov't Printing Office 1908), available at http://www2.census.gov/prod2/decennial/documents/1790m-02.pdf, also available at http://books.google.com/books?id=dbDiRQ2YOHYC. (The chart on page 8 breaks out free white males over sixteen and free white males under sixteen, but provides only a total figure for free white females, other free persons, and slaves. About $49 \%$ of free white males were over sixteen; applying that percentage to free white females and adding the number of free white males over sixteen yields an estimated total of about 216,000 free whites over sixteen.) The census does not appear to provide similar numbers for persons aged twenty-one or older. For more information on the number of Virginia Baptists in this approximate time period, see THOM, supra note 77, at 28-38.

252. See JAMES, supra note 251, at 163 (calling Culpeper "the strongest Baptist county in the district").

253. See LABUNSKI, supra note 57, at 175 (including chart showing total free population of Culpeper County as 13,879 , as compared to 8,407 for the next largest county, Amherst).

254. See, e.g., Letter from Burgess Ball to James Madison, supra note 234, at 385-86 ("On Culpeper much depends.... Thus sir, on Culpeper it is generally thought the desicion [sic] will depend."); Letter from James Madison to Edmund Randolph (Mar. 1, 1789), supra note 244, at 453 ("In Culpeper, which was the critical County, a continued attention was necessary to repel the multiplied falsehoods which circulated."); Madison's Election to the First Federal Congress, supra note 246, at 303 (noting that "[e]veryone agreed that Culpeper, which had a considerably larger voting population than any other county in the district, was crucial to the outcome"); LABUNSKI, supra note 57, at 156-57, 171-72; JAMES, supra note 251, at 163-64.

255. LABUNSKI, supra note 57 , at 162.

256. Id. at 159; see also MCCONNELL, supra note 19, at 57 (noting that the "Baptist constituents ... were a large and potentially decisive swing vote").

257. See LABUNSKI, supra note 57, at 150; Letter from Burgess Ball to James Madison, supra note 234, at 385 (stating that "Culpeper, you know, is much at the disposal of one Man," but also stating that "wd. you visit it [Culpeper] . . ., I've no doubt you wd. frustrate the designs of that Great Man") (emphasis in original); id. at $385 \mathrm{n} .2$ (editors' note identifying the "one Man" as Strother). 
be known is that Strother was particularly popular with Baptist voters; he had used his important role in the local Episcopal church as a vestryman to release an imprisoned Baptist preacher, apparently by tricking the Culpeper County jailers. ${ }^{258}$

Many Baptists, at least many in Orange County, had followed Leland in supporting ratification of the Constitution even though it lacked a bill of rights, in the expectation that a bill of rights would be considered post-ratification. ${ }^{259}$ But now the antifederalists--including Joel Early, the Culpeper County Baptist who had been an antifederalist delegate at the Virginia ratifying ${ }^{260}$-were repeating the charge that Henry had leveled against Madison in arguing that Madison should be denied a seat in the Senate: Madison supposedly thought (and had said) that the Constitution was perfect and thus, it was charged, he was against all amendments. ${ }^{261}$ This charge was particularly alarming to Baptists, ${ }^{262}$ who may have thought they had received assurances from Madison in connection with his election to the Virginia ratifying convention that serious consideration would be given to a bill of rights, and who almost certainly knew Madison had given such assurances during the Virginia ratifying convention. ${ }^{263}$ Baptist hostility would certainly doom Madison's candidacy, given the otherwise hostile nature of the gerrymandered district. But Baptist neutrality between Madison and Monroe likely also would result in Madison's defeat. He would need active Baptist support and a high percentage of the Baptist vote. ${ }^{264}$

258. See JAMES, supra note 251, at 59. Strother also had supported Madison and the Baptists in the religious assessment struggle of 1784-86. See Singleton, supra note 76, at 163-64.

259. See supra text accompanying notes 155, 172-80, 212-13, 222-24. Stuart Leibiger writes that

Leland's followers opposed the Constitution because they feared it did not sufficiently protect religious freedom. Madison changed the minister's mind, perhaps promising - if elected-to support recommendatory amendments guaranteeing liberty of conscience.... That Madison actually spoke of recommendatory amendments with Washington and Leland or in his stump speech cannot be proved. Only two weeks after stopping at Mount Vernon, however, he unequivocally advised Virginia's Federalists to emulate Massachusetts [by offering to pursue post-ratification amendments].

LEIBIGER, supra note 174 , at 92.

260. See infra note 321 .

261. See supra text accompanying notes 231-33 and infra text accompanying notes 273-79.

262. See LABUNSKI, supra note 57, at 143; see also id. at 163 ("He [Madison] knew that religious freedom was of grave concern to Baptists throughout the state.").

263. See supra note 259 and text accompanying notes 140-215, 223-26.

264. This election thus was quite different from the March 1788 ratifying convention election, in which Madison was running in friendly territory. In that election, heavy Baptist support was a luxury; all that Madison needed to win was for Baptists not to vote 
The antifederalists were committed to amending the Constitution to add a bill of rights. ${ }^{265}$ Throughout the Virginia ratifying convention Madison had continued to question the need for a bill of rights, arguing, even on June 24 , the day before the convention voted to ratify, that "[i]f an enumeration be made of our rights, will it not be implied, that every thing omitted, is given to the general government? Has not the honorable gentleman [George Wythe] himself, admitted, that an imperfect enumeration is dangerous?"266 Madison's main goal was to prevent a conditional ratification with previous amendments; he did, somewhat inconsistently, agree in the same speech that amendments enumerating rights could be favorably considered post-ratification even though they were not necessary, and he ultimately promised that amendments would be considered post-ratification. ${ }^{267}$ But Madison certainly could not claim to be more in favor of a bill of rights than his antifederalist friend and opponent, James Monroe, who, as noted above, had been a delegate to the Virginia ratifying convention ${ }^{268}$ and "an outspoken advocate of amendments" to the Constitution. ${ }^{269}$

How then could Madison hope to obtain the strong Baptist support he needed against Monroe? That hope could be based on at least five factors:

- his history of working with the Baptists in Virginia for religious freedom (including bringing an end to the establishment of the Episcopal church), with resulting trust in his integrity, in his commitment to principles of religious liberty, and in his abilities as a statesman;

- his greater experience in government and greater understanding of the new governmental system, which could enable him to be more effective in the new Congress;

- his association with George Washington; $;^{270}$

against him as a bloc. Their strong support for him turned the March 1788 election into a rout.

265. See, e.g., Finkelman, supra note 12 , at 305-07, 314, 322, 324-28, 340, 341-42, 344.

266. Madison's Speech of June 24, 1788, in 11 PAPERS OF JAMES MADISON, supra note 12 , at 175 .

267. Id. at 177 ; see supra text accompanying note 215 .

268. See supra note 240.

269. Leibiger, supra note 141 , at 458.

270. See KeTCHAM, supra note 75, at 276 (noting that at a Christmas Eve 1788 dinner party Washington "doubtless agreed to aid discreetly, as he had opportunity, in Madison's election to the House of Representatives") (footnote omitted). The Baptist General Committee's congratulatory letter to Washington, drafted by Leland, includes what would appear to be honest praise of Washington, reflecting his high standing among Baptists. See WRITINGS, supra note 12, at 52-54; Butterfield, supra note 2, at 194-95. 
- continued Baptist confidence that he would at least support serious consideration of a bill of rights if he were elected to Congress;

- the personal support he might receive from John Leland and other Baptist leaders, with Leland's support likely to be particularly important, given the high regard in which he was held and his leadership role in the Baptist General Committee, ${ }^{271}$ the point group for Baptists in political matters.

All of these but the third were threatened by the antifederalists' charges against Madison, though it is likely that Leland's support for Madisonas opposed to that of some other Baptist ministers-was never in doubt.

The Baptists were not the only ones who were alarmed by these antifederalist charges. Madison was too. He was charged, as noted above, with declaring at the Virginia ratifying convention that "the Constitution had no defects, and that it was the nearest to Perfection of any thing that Could be obtained"; ${ }^{272}$ thus he was accused of being

Baptists had enthusiastically supported the revolution, as Washington recognized in his response. See WRITINGS, supra note 12, at 54-55; Butterfield, supra note 2, at 195-96.

271. See supra note 155.

272. See Letter from George Turberville to James Madison (Nov. 16, 1788), supra note 232 , at $346-47$ ("Mr. Henry on yr. being nominated for the senate publicly declared in the house that you were not to be trusted with amendments since you had declared, that not a letter of the Constitution cou'd be spared -in Convention.") (emphasis in original); Letter from David Jameson, Jr. to James Madison (Jan. 14, 1789), in 11 PAPERS OF JAMES MADISON, supra note 12, at 419 ("I am informed by good Authority that Mr. Early reported that you were against any Amendments whatever, conceiving the Constn. a perfect one....").

The "Convention" in which, according to Henry, Madison had made this statement, apparently was the Virginia ratifying convention in Richmond, not the Philadelphia Convention. See 3 BRANT, supra note 88 , at 240 . But see LABUNSKI, supra note 57 , at 166-67 (stating that Joel Early accused Madison of having made that statement at the Philadelphia Convention). Neither Henry nor Early were delegates to the Philadelphia Convention; both were delegates to the ratifying convention, and thus could claim to have heard Madison make the statement if it were supposed to have been made at the ratifying convention. In addition, Early claimed that publication of "the Second Volume of the debates of the Convention" would prove that Madison made the statement, and Early claimed that the printer was delaying publication to prevent its contents from being used against candidates, obviously including Madison. Letter from Benjamin Johnson to James Madison (Jan. 19, 1789), supra note 92, at 423-24 (emphasis added). It is highly likely that this was a reference to the ratifying convention debates, as there was no project underway at the time to produce volumes of debates from the Philadelphia Convention for which a second volume (or any volume at all) would have been at the printers. For a discussion of the history of publication of the Philadelphia Convention debates, see Max Farrand, The Records of the Federal Convention, 13 AM. HIST. REV. 44 (1907), available at http://www.jstor.org/stable/1834886. Luther Martin's report to the Maryland legislature had been published earlier that year, see id. at $45-46$, but there is no indication that a second volume was anticipated. 
against all amendments ${ }^{273}$ and even of "ceas[ing] to be a friend to the rights of Conscience."274 Madison was concerned that these charges would be damaging:

It has been very industriously inculcated that I am dogmatically attached to the Constitution in every clause, syllable \& letter, and therefore not a single amendment will be promoted by my vote, either from conviction or a spirit of accommodation. This is the report most likely to affect the election, and most difficult to be combated with success, within the limited period. ${ }^{275}$

There also were related charges that could compound the damage. Madison was accused of tricking Virginia into agreeing to the Philadelphia Convention, ${ }^{276}$ apparently by secretly planning beforehand for the Convention to exceed its charter. He was also accused of holding up the printing of reports of the Virginia ratifying convention debates, ${ }^{277}$ because those reports, it was said, would prove the charge that he had declared the Constitution perfect in the ratifying convention. ${ }^{278}$

This was a multi-barreled assault on Madison's integrity, combined with the imputation of a position to him that was toxic to his election prospects: Madison's apparent agreement at the ratification convention that appropriate amendments would be considered post-ratification could not be trusted, and he was engaged in a cover-up so that voters would not realize he held a position-refusal to consider amendments- that they could not support.

If Madison could refute those charges-and especially if he could convince the Baptists that the charges were untrue - then he might have a chance to win. ${ }^{279}$ He refuted them through a letter-writing campaign (with some of the letters appearing in newspapers); through a series of personal campaign appearances (some of them joint appearances with Monroe) in at least the three counties of Orange, Culpeper, and

273. See LABUNSKI, supra note 57, at 158; Letter from George Nicholas to James Madison, supra note 87, at 406.

274. See Letter from James Madison to George Eve (Jan. 2, 1789), in 11 PAPERS OF JAMES MADISON, supra note 12, at 404.

275. Letter from James Madison to George Washington (Jan. 14, 1789), supra note 141 , at 418.

276. See LABUNSKI, supra note 57, at 158; Letter from George Nicholas to James Madison, supra note 87 , at 406.

277. 3 BRANT, supra note 88 , at 240 ; see supra note 272 .

278. See supra note 272.

279. LABUNSKI, supra note 57, at 159 ("Madison's primary challenge in the campaign was to let people know he did not oppose amendments."); Finkelman, supra note 12, at 335 (". . . Madison found that Baptist fears about religious liberty were sincere, strongly held, and had to be overcome if he was to win election."). 
Louisa ${ }^{280}$ and through the efforts of his friends, apparently including Leland ${ }^{281}$ and certainly including at least one other Baptist minister, George Eve. ${ }^{282}$ Labunski suggests Madison may have written dozens of campaign letters, ${ }^{283}$ though only four survive. ${ }^{284}$ Labunski stresses the importance of the Baptist vote by stating that the most important surviving letter was the one to George Eve. ${ }^{285}$ Madison devoted three of the four surviving letters-including the letter to Eve-to refuting the charge that he was against amendments; in those letters, and likely in his personal appearances and private conversations, he in effect pledged to "sponsor a bill of rights in the First Congress and work diligently toward its passage." 286

It should have been apparent to Madison that his relationships with Baptist leaders, and with Leland in particular, would be crucial to his effort to refute the antifederalists' charges. Little direct evidence has survived of Leland's role in the campaign, but it seems to have been substantial. The evidence that does exist consists mostly of two bookends, each occurring as Madison was leaving Virginia victorious, and of suggestive material to fill in between.

The first bookend is an event that took place as Madison was leaving Virginia for New York after the successful ratification effort in Richmond. On July 1, 1788, Madison sent his father two copies of the Federalist Papers, "one for Mr. Leland-the other for Mr. Bledsoe."287 The Baptists, particularly Leland, had helped Madison win election to the ratifying convention, and now Madison "looked upon [Leland and Bledsoe] as his agents among the Baptists of Orange and adjacent counties, who were still split on" the desirability of the Constitution. ${ }^{288}$ Leland could be extraordinarily persuasive, and it is unlikely Madison could have placed his trust in anyone more effective. Leland had been

280. See LABUNSKI, supra note 57, at 158-72; Madison's Election to the First Federal Congress, supra note 246, at 302-03.

281. See infra text accompanying notes $287-308$.

282. See infra text accompanying notes 308-28.

283. LABUNSKI, supra note 57, at 172.

284. Id. at 162; Madison's Election to the First Federal Congress, supra note 246, at 303.

285. LABUNSK1, supra note 57, at 162; see Letter from James Madison to George Eve (Jan. 2, 1789), supra note 274, at 404-05. The letter to George Eve also may be found in NOONAN, supra note 19, at 194-95.

286. LABUNSKI, supra note 57, at 159; see Madison's Election to the First Federal Congress, supra note 246, at 302-03; KETCHAM, supra note 75, at 276-77.

287. Letter from James Madison, Jr. to James Madison, Sr. (July 1, 178), in 11 PAPERS OF JAMES MADISON, supra note 12, at 185; see supra note 127 (noting that Bledsoe was a Baptist minister who preached at a church near Orange).

288. Butterfield, supra note 2, at 192. 
preaching in Virginia (and surrounding states) for eleven years. ${ }^{289}$ Later in his life, once he had been settled in Cheshire, Massachusetts for eight years, he so influenced Cheshire voters that tallies like 188 to 1 and 223 to 2 in favor of the Republican candidate for governor were typical; in the 1804 presidential election, the tally was 181 to zero in favor of Jefferson. $^{290}$

The other bookend is the letter Leland sent to Madison on about February 15, 1789, after Madison's victory in the Congressional election. ${ }^{291}$ After congratulating Madison, Leland refers to his "Undertaking in the Cause," though self-deprecatingly, and he humorously refers to Madison in the third person:

I congratulate you in your Appointment, as a Representative to Congress; and if my Undertaking in the Cause conduced Nothing else towards it, it certainly gave Mr. Madison one Vote. ${ }^{292}$

Leland proceeds in the letter to give Madison advice:

I expect that Congress will be very busy for some years, in filling a continental Blank with a Code of general Laws; and I think it will be very Judicious to send those Laws very liberally into the States, that their Eyes may always be open. No Danger of the Destruction of Liberty where the Community is well informed. Ignorance always brings on, either Mutiny or Lethargy, which equally pave the Way for Tyranny. ${ }^{293}$

Then Leland makes requests that, though gently made, would seem very presumptuous if Leland had not assisted substantially in the election. Leland again addresses Madison humorously in the third person and even suggests that Madison would be Leland's "particular Friend":

If Mr. Madison can get Leisure enough in Congress it would please my Fancy to have a List of all the Names of the Members of Congress; in which State they reside, and which House they fill: and it would inform my Mind to have an Account of all our National Debts; to what Powers they are due, and at what pr Cent; and likewise of our internal debt. And it would give me further Satisfaction to know (after the Trial) whether the Duties arising from Commerce are sufficient (without a direct Tax) for Supporting the federal Government, and the Payment of our Interest upon Debts. No

289. See supra text accompanying notes 54-62.

290. See Butterfield, supra note 2, at 215-16. "Leland's political influence may have become legendary, but it was no legend. It can be verified from the town records in the Cheshire clerk's office." Id. at 215.

291. Letter from John Leland to James Madison, supra note 80, at 442-43.

292. Id. at 442 (emphasis in original).

293. Id. 
doubt, there will be printed Statements, at proper Times; but I am so little acquainted with the literary and political World, that without the Aid of a particular Friend, I shall never see them. If I could see all the Laws I should be glad, altho' in Person, I have little Use for them. ${ }^{294}$

Going beyond gentle requests, Leland then expresses a firm expectation, almost a demand. Again, this would seem presumptuous absent a political alliance that would have involved Leland making efforts to help Madison win the election:

One thing I shall expect; that if religious Liberty is anywise threatened, that I shall receive the earliest Intelligence. ${ }^{295}$

Leland closes by assuming that Madison would stop by Leland's home for a discussion on his way to the new federal Congress in New York, but of course Leland (an itinerant preacher who was also serving a local church in another county ${ }^{296}$ ) might not be home:

I take the Liberty of writing thus to you, lest I should not be at Home when you pass by on your Way to Congress. ${ }^{297}$

These bookends suggest that it is highly likely that Leland made substantial efforts to help Madison win the Congressional election. It must be admitted, though, that direct evidence to fill in between the bookends is sparse.

We know that George Nicholas wrote to Madison on Friday January 2, 1789, (a few days after Madison arrived home) to say that Leland had "great influence in Louisa and Goochland" counties and to suggest that Leland "be prevailed on to exert himself." 298 It seems unlikely that Madison would have ignored this advice or that Leland would have refused to help. On Monday January 12, 1789, Benjamin Johnson, who seemed to be acting as Madison's agent, wrote Madison to say that he had left a message with Sally Leland on Friday the $9 \mathrm{th}^{299}$ John Leland was not home because he was on a three-day preaching tour (January 9th

294. Id. at $442-43$ (emphasis in original). Buckley confidently states that, "[r]emembering Madison's role in the passage of Jefferson's bill, both Eve and Leland supported his election [to Congress]. Evidently they made a difference." Buckley, supra note 89 , at $42-43$.

295. Letter from John Leland to James Madison, supra note 80, at 443.

296. See supra note 59 and accompanying text.

297. Letter from John Leland to James Madison, supra note 80, at 443.

298. Letter from George Nicholas to James Madison (Jan. 2, 1789), in 11 PAPERS of JAMES MADISON, supra note 12, at 408.

299. See Letter from Benjamin Johnson to James Madison (Jan. 12, 1789), in 11 PAPERS OF JAMES MADISON, supra note 12, at 414-15. The letter was sent on January 12 , 1789 , which was a Monday. The previous Friday, when Johnson's letter says he stopped at Leland's home, would then have been January 9th. 
to 11 th) of Culpeper County. ${ }^{300}$ The message asked Leland to let Madison know when and where the "Baptist Ministers of this district" (presumably the Congressional district) would be holding their planned political meeting; all that Johnson knew was that it was to be held in Louisa County. ${ }^{301}$ And on Monday, January 19, 1789, Leland gave Johnson a letter to deliver to Madison, which Johnson delivered as an enclosure with his letter to Madison of the same date. ${ }^{302}$ Johnson's letter survives; Leland's apparently does not, though the fact of its writing provides some evidence of Leland's involvement.

The election results certainly provide evidence that the Baptists ended up supporting Madison, who won by 336 votes-1,308 to 972-in the heavily antifederalist district. ${ }^{303}$ Madison swept his (and Leland's) home county of Orange 216 to 9, which would have been impossible without strong Baptist support. The margin resembles those Leland assembled for Republicans years later in Cheshire. ${ }^{304}$ (By comparison, Monroe outpolled Madison only 189 to 115 in Monroe's home county of Spotsylvania.) Madison took Louisa County (the county in which Leland pastored a church) by a vote of 228 to 124 , nearly two to one; it had been equally enough divided in the March 1788 ratification convention election that it elected one federalist and one antifederalist. ${ }^{305}$ And Madison prevailed in Culpeper County, with its many Baptists, 256 to 103 , more than two to one. The Culpeper County result was a complete turnaround from the March 1788 election, in which the voters chose antifederalist Joel Early and another antifederalist as its two

300. Id.

301. Id.

302. Letter from Benjamin Johnson to James Madison (Jan. 19, 1789), in 11 PAPERS OF JAMES MADISON, supra note 12 , at 423.

303. See LABUNSKI, supra note 57, at 175 (providing a chart showing, for each county of the district, the number of eligible voters, the number of votes for Madison and for Monroe, the total number of votes, the turnout percentage, and the total free population); Madison's Election to the First Federal Congress, supra note 246, at 304 (noting countyby-county tallies and total district vote as reported in Feb. 12, 1789 Fredericksburg Virginia Herald newspaper). The county-by-county vote tallies discussed in the text in the remainder of the paragraph are taken from these two sources. Michael McConnell notes that when Madison

initiated his candidacy for Congress, he discovered that his Baptist constituents were prepared to throw their support to his opponent, James Monroe. On advice of his political adviser, George Nicholas, Madison contacted Baptist leaders and proclaimed his support for "the most satisfactory provisions for all essential rights, particularly the rights of Conscience in the fullest latitude." $\mathrm{He}$ then championed a constitutional provision for religious liberty as a campaign issue. The Baptist leaders responded by giving him their electoral support, which contributed to his narrow margin of victory.

McConnell, supra note 37, at 1477 (footnotes omitted).

304. See supra text accompanying note 290.

305. JAMES, supra note 251, at 161; LABUNSKI, supra note 57, at 150. 
convention delegates "probably ... by substantial margins." be said, however, that the vote in Goochland County, where Leland was said by Nicholas to have great influence, was a near tie, 133 for Monroe to 132 for Madison. ${ }^{307}$

These results could easily reflect substantial efforts by Leland and are otherwise somewhat difficult to explain. In light of the bookends discussed above-Madison's reaching out to Leland after the Virginia ratifying convention and Leland's letter to Madison after the congressional election-and in light of Leland's leading role among Baptists on political issues, it seems likely that Leland did work hard to elect Madison and that his work paid off. This conclusion is not, however, free from doubt.

It is clear, however, as noted above, that another Baptist minister helped Madison win the election. The minister, George Eve, helped Madison by defending him at a Baptist meeting, after first receiving a letter from Madison in which Madison committed himself to work toward the adoption of a bill of rights. ${ }^{308}$ The story is well known, but it has generally been assumed that the meeting occurred at the Blue Run Baptist church in Orange County. ${ }^{309}$ In fact, it almost certainly happened at the Rapidan Baptist church in Culpeper County, which perhaps helps to explain Madison's success there.

The story begins with a request from George Eve, probably in late December, 1788. At the time Eve, "one of the most successful preachers in these parts," 310 was serving as pastor for three churches: Blue Run in Orange County, Prethis Creek in Albemarle County, and Rapidan in Culpeper County. ${ }^{311}$ Rapidan apparently was the church where Eve was called to service ("raised up") and in which he was ordained to the ministry in "about 1775."

306. LABUNSKI, supra note 57, at 150.

307. The vote tallies for the other three counties in the district were:

$\begin{array}{lll} & \text { Madison } & \text { Monroe } \\ \text { Albemarle } & 174 & 105 \\ \text { Amherst } & 145 & 246 \\ \text { Fluvanna } & 42 & 63\end{array}$

Madison's Election to the First Federal Congress, supra note 246, at 304; LABUNKSI, supra note 57, at 175. Madison did better than expected in Amherst County; Amherst was dominated by the antifederalist Cabell family, who had a very effective turnout machine. Id. at 140.

308. See infra text accompanying notes 311-29.

309. See infra note 321.

310. SEMPLE, supra note 38 , at 238.

311. Id. at $240-41 ; 224,224$ n.*, 238-39 (noting that Rapidan church was a "daughter" church of Blue Run).

312. Id. at 238. The editors of Madison's papers state that Eve was ordained in 1778. 11 PAPERS OF JAMES MADISON, supra note 12, at $405 \mathrm{n} .1$. 
persecution; its earlier pastor, Elijah Craig, had been "taken out of the pulpit and committed to Culpeper jail[,]" member Adam Banks was jailed for "praying in [a] private house," and there had been other incidents of persecution. ${ }^{313}$

Eve had heard the charges the antifederalists were making against Madison and, apparently in a conversation with Madison's brother, William, ${ }^{314}$ "asked for a statement" refuting them. ${ }^{315}$ Madison wrote to Eve on January 2, 1789, admitting he did not see as great a need for amendments as others saw and that he had opposed pre-ratification amendments. ${ }^{316}$ But now, with the Constitution firmly established by eleven states' ratifications,

amendments, if pursued with a proper moderation and in a proper mode, will not only be safe, but may serve the double purpose of satisfying the minds of well meaning opponents, and of providing additional guards in favour of liberty. Under this change of circumstances, it is my sincere opinion that the Constitution ought to be revised, and that the first Congress meeting under it, ought to prepare and recommend to the States for ratification, the most satisfactory provisions for all essential rights, particularly the right of Conscience in the fullest latitude, the freedom of the press, trials by jury, security against general warrants $\& \mathrm{c} .{ }^{317}$

As Labunski points out, Eve would have received the letter in time to "share Madison's sentiments about a proposed amendment on religious freedom with congregations throughout much of the district and in person at scheduled services." 318 Labunski seems to be on solid ground in concluding that the letter probably had a substantial effect on the Baptists, "especially in populous Culpeper County, where they had suffered persecution[.]"319

Presumably, Eve had received the letter and was able to refer to it when he defended Madison on January 18, 1789, at what seems to have

313. SEMPLE, supra note 38 , at 238 ("When the Gospel was first preached in the bounds of this church persecution ran high."). At that time Elijah Craig was the pastor not only of the Rapidan church in Culpeper County but also of the Blue Run Church in Orange County. Id. at 240-41. For a list of Baptists who had been imprisoned in the Culpeper jail, including Elijah Craig and Adam Banks, see THOM, supra note 77, at 26 n.38.

314. Letter from James Madison to George Eve, supra note 274, at 404.

315. 3 BRANT, supra note 88 , at 240.

316. Letter from James Madison to George Eve, supra note 274.

317. Id. at 404-05.

318. LABUNSKI, supra note 57 , at 165.

319. Id. 
been a regular service ${ }^{320}$ at the Rapidan church in Culpeper County (not, as has often been thought, the Blue Run church in Orange County). ${ }^{321}$

320. See Letter from Benjamin Johnson to James Madison, supra note 92; Butterfield, supra note 2, at 193; 3 BRANT, supra note 88, at 240 (stating that "Mr. Eve was all primed when on January 17, 1789, Messrs. Banks and Early converted his Saturday evening church service into an anti-Madison political meeting"). In his letter to Madison, Johnson describes the meeting as "Mr. Eve's Meeting" and "their Chu[r]ch Meeting." Johnson, supra note 92, at 423. Labunski states that Eve went to the meeting in case there was a need to defend Madison. LABUNSKI, supra note 57, at 167 . Ketcham similarly says Eve "attended a Baptist meeting antifederalists were using for political purposes[.]" KeTCHAM, supra note 75, at 276. Given Johnson's description, it seems much more likely that Eve was there to conduct the church service, which then veered into politics.

321. It has generally been thought that the meeting was at the Blue Run church. See, e.g., MCCONNELL, supra note 19, at 57; JOHN T. NOONAN, JR., THE LUSTRE OF OUR COUNTRY: THE AMERICAN EXPERIENCE OF ReligIOUS FREEDOM 78 (1998); Butterfield, supra note 2, at 193. However, it almost certainly was at the Rapidan church. Note that Eve was pastor of both. See supra text accompanying notes 310-11. Records show that two of the other key persons noted in Johnson's letter were members of or at least had close connections with the Rapidan church and Culpeper County: Adam Banks, who brought the motion for the assembled body to consider the election, and "Mr. Early"Joel Early, as noted below-who seconded the motion and then led the attack on Madison. Johnson, supra note 92.

As noted above, Banks was a Rapidan church member who had been jailed for his religious activities sometime in the 1770s. See supra text accompanying note 313. Banks was still an elder of the Rapidan church as late as 1806 , when the elders purchased land for the church from four persons, three of whom were members of the Early family, including Joel Early's nephew Paschal Early. See Ruth H. Early, The Family of EARLY 22-23, 209 (Lynchburg, VA, Brown-Morrison Co. 1920), available at http://books.google.com/books?id=vI5IAAAAMAAJ. For additional information about Banks, see the sources cited by the editors of Madison's Papers, 11 PAPERS OF JAMES MADISON, supra note 12, at 424 n. 1 .

The "Mr. Early" mentioned in Johnson's letter was, as Labunski says, Joel Early, a Culpeper County delegate to the Virginia ratifying convention who voted against unconditional ratification, and whom Labunski describes as a "fervent Anti-Federalist." LABUNSKI, supra note 57, at 150, 166-67; see 11 PAPERS OF JAMES MADISON, supra note 12, at 419-20 n.2 (identifying Joel Early as the "Mr Early" who was reported in Jameson's letter (Jameson, supra note 272) to be spreading accusations in Culpeper County that Madison was against amendments). Joel Early's vote for ratifying the Constitution only with prior amendments is recorded in Ruth Early's history of the family, which also notes that Joel was a Culpeper resident until he moved to Kentucky in 1791. EARLY, supra, at 293-94. The Early family had close connections with the Rapidan church beyond Paschal Early's sale of land to the church. Joel's brother Joseph Early (Paschal's father) had been a distinguished member of the Rapidan church before he died in 1783. SEMPLE, supra note 38, at 239; EARLY, supra, at 207. Joseph even is reported to have built the Rapidan church meeting house. EARLY, supra, at 207. When Joel was planning to move to Kentucky, he sold his deceased father's "Manor house and plantation," along with other real property, to Rapidan church member Adam Banks in 1791. Id. at 294.

It also seems clear that Joel Early was a member of the church where the meeting was held, which also suggests strongly that it was held at the Rapidan church. Only a church member likely would have been entitled to second a formal motion in a church meeting, especially a motion for the church to take a united position on an issue, given the Baptists' strong views that each local church is self-governing under democratic 
Adam Banks ${ }^{322}$ presented a motion, seconded by Joel Early, ${ }^{323}$ for the church to "go into the business of the approaching Election, and endeavour to unite on the Occasion." 324 In effect, Early was suggesting that the church should pick a candidate and support that candidate as a group. Early repeated his accusations: that in the Virginia ratifying convention Madison had said that "the Constitution had no defects, and that it was the nearest to Perfection of any thing that Could be obtained;" that this could be proved if the report of the debates were published; and that publication was being held up to help candidates, obviously including Madison. ${ }^{325}$ Eve sprang to Madison's defense. As Johnson recounted it for Madison, Eve

took a very Spirited and decided Part in your favour, he Spoke Long on the Subject, and reminded them of the many important Services which you had rendered their Society, in particular the Act for establishing Religious Liberty, also the bill for a general Assessment; which was averted by your Particular efforts; Mr. Eve urged that he thought they were under Obligations to you, and had much more reason to place their Confidence in you, than Mr. Monroe. . . ${ }^{326}$

When it was suggested that Madison had voted against seizure of the Episcopal glebe lands-and thus against a fervently-held Baptist position-Eve responded that Monroe also had voted against the seizure, and had broken a promise to a prominent Baptist in doing so. ${ }^{327}$

Based on conversations with Baptists after the meeting, Johnson thought Eve "ha[d] given a great wound to Mr. Earlys Cause," and that, if there were "no insidious means taken in future," Madison would "get a good vote from that Quarter."328

It seems apparent that Madison indeed did get a "good vote" from Baptists, and not just in Culpeper County. In modern terminology, Madison's outreach to a faith community had paid off.

principles. Note that Banks's motion was to "go into the business of the approaching Election, and endeavour to unite on the Occasion." Johnson, supra note 92, at 423. Thus it was very much a matter for the church members. In addition, it would be strange for Joel to be a member of Blue Run church in Orange County, when he lived in Culpeper County and had close family ties to a Culpeper County church, the Rapidan church.

The evidence thus is very strong that the meeting was at the Rapidan church, not the Blue Run church.

322. See supra note 321 and text accompanying note 313 .

323. See supra note 321 and text accompanying notes $233,260$.

324. See Letter from Benjamin Johnson to James Madison, supra note 92, at 423.

325. Id. at 423-24; see supra note 272.

326. Id at 424 .

327. Id.

328. Id. 
The faith community got what it wanted, too, and the entire nation benefitted. ${ }^{329}$ Of course, once in the Congress, Madison followed through on his commitment. He moved forward on amendments with skill and determination, as Paul Finkelman has shown in his insightful explanation of Madison's views, motivations, and strategy. ${ }^{330}$ Madison proposed amendments that ultimately became the Bill of Rights, not because he thought they were necessary but because he felt bound by his commitment, and because he saw other benefits to adoption of such amendments. ${ }^{331}$ Adoption of carefully drafted amendments would not, he decided, create dangers, and might be of some help in protecting liberty. Adoption of amendments would help to unify the country by reconciling moderate antifederalists to the Constitution and the new federal government, perhaps at the same time convincing North Carolina and Rhode Island to ratify the Constitution. Most importantly, adoption of amendments would reduce the pressure for a second Constitutional Convention; Madison feared that a Convention would spin out of control and propose major structural changes - changes that would weaken the new federal government and make it ineffective. ${ }^{332}$

Madison even tried to get Congress to propose an amendment that would protect the people's rights against their state governments. The proposal was to insert the following language in Article I, section 10 after the first paragraph:

$[\mathrm{N}] \mathrm{o}$ state shall infringe the equal rights of conscience, nor the freedom of speech or of the press, nor of the right of trial by jury in criminal cases. ${ }^{333}$

Madison argued that this was "the most valuable amendment in the whole list." 334 The House agreed to it; the Senate did not; and the amendment failed. ${ }^{335}$ Had it been adopted, Leland might not have had to

329. See, e.g., McConnell, supra note 7, at 646 (noting, after discussing Baptist support for Madison's election to the First Congress, "[w]ere it not for 'religious activists,' we might not have a First Amendment'); Douglas Laycock, Religious Liberty as Liberty, 7 J. CONTEMP. LEGAL IsSUES 313, 346 (1996) ("But for the Virginia Baptists, we might not have a Bill of Rights.").

330. Finkelman, supra note 12, at 336-47.

331. Id. at 337.

332. Id.

333. 1 ANNALS OF CONG. 783-84 (Joseph Gales, Sr. ed., 1834), available at; http://memory.loc.gov/ammem/amlaw/lwaclink.html; see MCCONNELL, supra note 19 , at 57-58. (The Google Books project includes images from what appears to be a slightly different 1834 edition of volume one of the Annals of Congress, in which the relevant page citation is page 755 rather than 783-84. See http://books.google.com/books? id= xh0TAAAAYAAJ.)

334. I ANNALS OF CONG., supra note 333, at 784; MCCONNELL, supra note 19, at 6162.

335. Finkelman, supra note 12, at 344; MCCONNELL, supra note 19, at 62 . 
struggle for so many years to bring religious liberty to New England and to end the Congregationalist establishment, after he moved back there in $1791 .^{336}$ Yet Leland and the Virginia Baptists were very pleased with the results of Madison's efforts. When Congress sent the Bill of Rights to the states for ratification, Leland sent word to Madison that the Baptists were "entirely satisfied." 337

\section{CONCLUSION}

John Leland, Baptist preacher, was politically involved, as were many other Virginia Baptists. He was involved as a Baptist preacher, not just as a private citizen. The evidence shows that Madison very likely sought his help in the March 1788 election that sent Madison to the Virginia ratifying convention, ${ }^{338}$ and also in the February 1789 election that sent Madison to the First Congress ${ }^{339}$ - help that may have been decisive in each case. The success of the Constitution may have depended on Madison's presence at the Virginia ratifying convention; and the adoption of the Bill of Rights may have depended on Madison's presence in the First Congress. ${ }^{340}$ Thus, Leland, acting as a politically involved minister, may have helped to shape the structure of American government and the scope of Americans' individual rights. Much of the evidence is circumstantial, as Butterfield suggests with regard to whether Madison met with Leland before the March 1788 election, ${ }^{341}$ but the evidence is nevertheless, in your author's view, persuasive.

The twin focuses of this article have been first, to introduce Leland to those who may not have been aware of his importance and of his incisive and accessible approach to issues of religious freedom, and second, to present and evaluate the evidence of Leland's involvement in Madison's March 1788 and February 1789 elections. This article has not focused on how that involvement should affect our interpretation of the Religion Clauses of the First Amendment. To the extent that the original understanding of the language of those Clauses is at issue, Leland's public involvement with Madison's political fate may provide important context. To the extent that Madison's understanding of what he was proposing is relevant-perhaps because of our respect for his intellect or

336. See Butterfield, supra note 2, at 196-241; Marci A. Hamilton \& Rachel Steamer, The Religious Origins of Disestablishment Principles, 81 NOTRE DAME L. REV. 1755, 1776 (2006) ("Baptist pastor John Leland, an eloquent and forceful proponent of the freedom of conscience, as well as the separation of church and state, was the only man to oppose establishments in Massachusetts, Virginia, and Connecticut.").

337. Alley, supra note 83 , at 43.

338. See supra text accompanying notes 131-224.

339. See supra text accompanying notes 259-329.

340. See Finkelman, supra note 12, at 304.

341. See supra text accompanying note 168 . 
for other reasons-Leland's involvement similarly could be quite important. Leland's own writings on religious freedom, when understood in the light of his actions, may also help us to understand how full participation of religious persons, as religious persons, in the public square can be consistent with full protection of rights of conscience for all persons.

Much then remains to be done to consider the implications of Leland's political involvement for our understanding of law and religion, and of the Religion Clauses. His involvement may also have implications for our understanding of the constitutional issues, and the broader policy issues, regarding tax laws and political involvement of churches. Should the law-including the Internal Revenue Codediscourage religious leaders, as religious leaders, from being active in politics? And we certainly can ask what people of faith may be able to learn from John Leland about how to be politically involved in service of freedom of conscience for all.

A particular question that may need to be answered is how Leland's activities should be characterized. Did he simply act, as a religious leader, to protect religious freedom? If so, then perhaps his involvement does not provide a justification for broader involvement of religious leaders in political issues generally. But his support for Madison's elections to the Virginia ratifying convention and to the First Congress may be hard to characterize that way. Leland helped Madison become a Virginia ratifying convention delegate not primarily to protect religious freedom from the proposed federal government; he could have done that perhaps more effectively by supporting the antifederalist candidates who would have tried to prevent a strong federal government from being created at all. But Leland apparently understood that America needed a stronger central government than the one provided by the Articles of Confederation; thus he supported Madison and trusted that Madison in turn would do what he could to protect religious liberty. In the congressional election both candidates supported amendments to protect rights of conscience. If anything, Monroe was more committed to such amendments. Again, Leland's support for Madison was based more on the understanding that the framework of government that Madison had helped to create-and that he would work to preserve-was a framework that would preserve the common good. In the words of the Preamble, Leland may have been politically active not just to protect religious liberty, but also, to "promote the general welfare." He did so even when that may have created a risk to religious liberty, placing his trust in Madison to ensure that religious liberty would be protected.

In the midst of these questions, we should not lose sight of two final points. First, as others have noted, Leland was first and foremost a 
minister of the Gospel. ${ }^{342}$ His focus was on saving souls, as he would describe it. His sermons seldom would end without coming back to chapter three of the Gospel of John, which speaks of the need for a new birth, and tells the basic message of the Christian Gospel. He traveled extraordinary distances, speaking anywhere and everywhere that he could, to spread that message, but always with respect for the rights of conscience and the religious liberty of all, including those who had no interest in his message.

Second, John Leland can speak to us from his time, with humor, with sympathetic understanding, and with a message, rooted in his Christian faith, of the value of the individual. It is good to read old books, like The Writings of the Late Elder John Leland, not for antiquarian interest, but for understanding. As C.S. Lewis explained

Every age has its own outlook. It is specially good at seeing certain truths and specially liable to make certain mistakes. We all, therefore, need the books that will correct the characteristic mistakes of our own period. And that means the old books. All contemporary writers share to some extent the contemporary outlook-even those, like myself, who seem most opposed to it. Nothing strikes me more when I read the controversies of past ages than the fact that both sides were usually assuming without question a good deal which we should now absolutely deny. ... None of us can fully escape this blindness, but we shall certainly increase it, and weaken our guard against it, if we read only modern books. Where they are true they will give us truths which we half knew already. Where they are false they will aggravate the error with which we are already dangerously ill. The only palliative is to keep the clean sea breeze of the centuries blowing through our minds, and this can be done only by reading old books. Not, of course, that there is any magic about the past. People were no cleverer then than they are now; they made as many mistakes as we. But not the same mistakes. They will not flatter us in the errors we are already committing; and their own errors, being now open and palpable, will not endanger us. Two heads are better than one, not because either is infallible, but because they are unlikely to go wrong

342. See Gaustad, supra note 12 , at 134 . Gaustad notes that

[t]he labors of both Backus and Leland speak most eloquently of their evangelistic zeal. This deserves to be emphasized and remembered, because their words so often seem to focus on temporal concerns-particularly the words most frequently quoted. Any balanced point of view will recognize that their major business was the saving of souls. Their pronouncements on church and state could have been made from the fireside, without the mounting of horses and riding something like 70,000 miles each. But each labored in an unbounded vineyard, "faint yet pursuing," as Leland said, until the end of their days. 
in the same direction. To be sure, the books of the future would be just as good a corrective as the books of the past, but unfortunately we cannot get at them. ${ }^{343}$

Can Leland help us to escape our period's "characteristic mistakes"? Perhaps. After all, if Lyman Henry Butterfield-"not one who found much use for religious symbols or for religion as an institution"344 could say, after spending years editing Jefferson's papers, that John Leland, an itinerant Baptist preacher, "was as courageous and resourceful a champion of the rights of conscience as America has produced"345 - as courageous and resourceful as Jefferson?-perhaps Leland has something to say to us.

343. C.S. Lewis, Introduction to ATHANASIUS, ON THE INCARNATION OF THE WORD OF GoD (1946) (trans. by "A Religious of C.S.M.V. S.Th.") (emphasis in original), reprinted as On the Reading of Old Books, in C.S. LEWIS, GOD IN THE DOCK: ESSAYS ON THEOLOGY AND ETHICS 200, 202 (Walter Hooper ed., Wm. B. Eerdmans Publishing 1970, reprinted 1994). The 1946 American edition of ON THE INCARNATION was published by the Macmillan Company following the book's initial publication in England in 1944 by the Centenary Press. A second revised edition (including Athanasius' letter on interpretation of the Psalms and with the same introduction by Lewis) was published in England in 1953 by A.R. Mowbray \& Co, Ltd. and in the United States in 1993 by St. Vladimir's Seminary Press. The 1993 edition is still in print; a limited preview of it is available on Google Books at http://books.google.com/books?id=WvrRvaDvO4QC.

As Walter Hooper's preface notes, GOD IN THE DOCK is a posthumous collection of some of Lewis's essays and letters, most of which had not previously been published. The title given by Hooper to one of the essays also gives the collection its title. Bryan Garner reminds us that "dock, in British legal writing, means 'the enclosure in a criminal court in which the prisoner is placed during trial." "BRYAN A. GARNER, A DICTIONARY OF MODERN LEGAL USAGE 289 ( 2 d ed. 1995). In that essay, Lewis writes, "The ancient man approached God (or even the gods) as the accused person approaches his judge. For the modern man, the roles are reversed. He is the judge; God is in the dock." God in the Dock, in GOD IN THE DOCK 240, 244 (originally published, as noted in Hooper's preface, as Difficulties in Presenting the Christian Faith to Modern Unbelievers, 3 LUMEN VITAE 421 (September 1948)). A limited preview of GOD IN THE DOCK is available at $\mathrm{http} / /$ /books.google.com/books?id=I6xWiVDThpEC.

344. See supra note 2.

345. See supra introductory quotation accompanying note 2 . 